\title{
MOMENTOS DA ARTICULAÇÃO COMUNITÁRIA DA VEREINIGUNG: DIALÉTICA E SOCIEDADE NO JOVEM HEGEL
}

\author{
Erick Calheiros de Lima \\ Pós-doutorando em Filosofia - UNICAMP
}

\begin{abstract}
The paper attempts to investigate the relation between dialectic and society in the work of the young Hegel. In order to do this I consider the development of Hegel's notion of community in Frankfurt and Jena: first, the societal articulation of Vereinigung through the concepts of love, life and fate; secondly, the critique of the Reflexionsphilosophien out of the previous conception of unification; and finally, in Jena's early writings, the relation between the individual's excluding self-position and the ties constitutive of the 'being-one' of community and the individual.
\end{abstract}

keywords: Dialectic, community, ethical life, ethics, G.W.F Hegel.

Resumo: Recorrendo a textos de Hegel do período de Frankfurt e de Jena, o objetivo é investigar o vínculo entre dialética e sociedade no jovem Hegel, tomando como fio condutor os momentos pelos quais sua noção de comunidade se constitui: primeiramente, a articulação societária da Vereinigung com os conceitos de amor, vida e destino; em segundo lugar, a operacionalização da Vereinigung em uma crítica da filosofia da reflexão; finalmente, nos primeiros textos de Jena, a relação entre a posição excludente do singular e a intensificação dos laços que compõem o Einssein da comunidade e do indivíduo.

Palavras-chave: Dialética, comunidade, eticidade, ética, G.W.F. Hegel.

\section{Introdução}

Este trabalho pretende reconstruir os principais passos pelos quais se dá a constituição do teor societário da noção de universalidade no jovem Hegel. O fio condutor para este percurso será o exame da articulação sócio- 
filosófica do conceito de Vereinigung, precursor das noções hegelianas maduras do universal concreto, vinculado à lógica especulativa, e de eticidade, ligada à sua filosofia do espírito objetivo.

Primeiramente, pretende-se caracterizar a primeira enunciação da Vereinigung como amor, ainda no período de Frankfurt. Em segundo lugar, procurar-se-á evidenciar, a partir do misticismo próprio à noção de destino, como o jovem Hegel articula socialmente esta noção em uma compreensão da comunidade como capaz não somente de "nadificar" a posição excludente do singular, mas de tornar este movimento o processo de intensificação de seus laços. Em terceiro lugar, em uma consideração digressiva sobre a constituição do ponto de vista especulativo, mostrar-se-á como a noção de unificação é operacionalizada em uma crítica da filosofia da reflexão. Este último passo deve ser compreendido apenas como um preâmbulo para a caracterização, feita na quarta parte, do conceito jenense de eticidade absoluta, cunhado por Hegel no contexto de sua crítica às compreensões individualistas da realização social da liberdade. Finalmente, pretende-se mostrar como Hegel aglutina, no System der Sittlichkeit, as principais motivações de Frankfurt e de Jena vinculadas a uma articulação sóciofilosófica da Vereinigung: a auto-intensificação dos nexos comunitários pela nadificação ${ }^{1}$ da posição excludente do singular é ligada a uma noção especulativa de eticidade, a qual, ao fornecer o arcabouço para uma crítica da noção contratualista de associação, pretende constituir-se como quadro comunitário capaz de efetivar a liberdade individual.

\footnotetext{
11 O verbo vernichten, do qual deriva o substantivo Vernichtung, ocorre em todos os textos de Hegel que se referem ao percurso adotado neste trabalho. Entretanto, sua mais ou menos clara dissemia, que perpassa tais textos, cria alguns inconvenientes para uma versão constante do termo em português. Por isso, adotou-se aqui a seguinte orientação, a qual não pretende ser nem exaustiva, nem definitiva, permanecendo assim temporária e passível de discussão futura, tão logo uma solução satisfatória seja encontrada. Quando o termo se refere mais ao poder aniquilador da negatividade absoluta, capaz de dissolver, em geral, todas as determinações, preferiu-se justamente o termo aniquilação, o qual aparece freqüentemente também em um contexto metafórico, que apela à figuração do poder absoluto do conceito. Entretanto, quando o contexto no qual os derivados de vernichten oferecem uma interpretação mais positiva da nulificação das determinidades, a qual justamente fornece a "passagem especulativa" à compreensão positiva da indiferença e da identidade absolutas, preferiu-se o neologismo nadificação.
} 


\section{Antecipação da Vereinigung nos nexos sócio-filosóficos do Amor: Hegel em Frankfurt}

O panorama filosófico em que se desenvolve a compreensão do amor no jovem Hegel, marcado pelas tentativas pós-kantianas de ultrapassar as dicotomias de um kantismo considerado dogmático, dota este conceito de um significado especulativo que está na base da relação estabelecida por Hegel em Jena entre a especulação e a reflexão, bem como de sua tese histórico-filosófica e ontológica acerca da conexão entre a "reflexão" e a “cisão das relações vitais” (HEGEL, 1970, II, 21/22). Em linhas gerais, na passagem de Frankfurt para Jena, Hegel é despertado para a necessidade de um novo paradigma de filosofia, originado do tema da Vereinigung, cuja primeira implementação não é ainda a compreensão jenense de especulação, mas um princípio de sistema, explicitado ao fim do período de Frankfurt no Systemfragment 1800, ancorado numa "metafísica do ser e da vida" e que, de maneira resumida, pretende ser uma superação de Kant pela assimilação de Espinosa (BONDELI, 1997, 117).

Do ponto de vista da filosofia prática, o desenvolvimento da noção de Vereinigung como amor está associado, sobretudo, à formulação de um ponto de vista capaz de ultrapassar a dicotomia fundamental da moral kantiana entre os princípios racionais e os potenciais obstáculos à vida ética suscitados pela sensibilidade. Em Frankfurt, Hegel se distancia, por um lado, da orientação kantiana quanto a uma compreensão racional da religião como pressuposto de sua imposição não autoritária ou não positiva; ainda que, de outro, mantenha a preocupação dos períodos anteriores com o resgate do poder sócio-integrador da religião em circunstâncias modernas. Este contexto, no qual Hegel se depara, assimilando a radicalização das cisões operada por Fichte, com as insuficiências da reflexão para a compreensão da Vereinigung, é também o ensejo para a abordagem dos aspectos sociais da mesma, quando o amor assume um papel de destaque justamente como significação social da unificação.

A primeira tematização decisiva do tema da Vereinigung em Hegel se encontra nos Entwürfe über Religion und Liebe, esboços que evidenciam a formação filosófica de Hegel intensamente influenciada por Fichte e por 
Hölderlin (JAMME, 1988, 1990)². Diferentemente de Schelling e Hölderlin, os quais, partindo do problema do "fundamento de unidade do suprasensível” (KANT, 1968, V, BXX), tencionam, ainda que diversamente, uma mediação mais profunda entre Kant e Espinosa, Hegel considera, por outro lado, o problema da Vereinigung sobretudo no registro da vida éticocomunitária a que é conduzido por suas investigações acerca do cristianismo. O conceito de amor se torna significativo para o problema da "integração" social na medida em que a "ética do amor", formulada no opúsculo posterior, Espírito do Cristianismo, como crítica e superação da dicotomia fundamental da moral deontológica e da "separação" entre indivíduo e comunidade, origina-se da absorção hegeliana do tema da Vereinigung. Portanto, é no horizonte do aprofundamento sócio-filosófico desta absorção que se deixa entender o recurso de Hegel à dicotomia entre natureza e liberdade, tão importante no registro kantiano do problema da realizabilidade da liberdade.

"Se lá, onde na natureza há eterna separação, algo incompatível (Unvereinbares) for unificado, aí há positividade. Este unificado, este ideal é, portanto, objeto, e há nele algo que não é sujeito.” (HEGEL, 1970, 1, 244) Contra a "positividade" de uma união forçada entre sujeito e objeto, denunciadora de sua não-identidade, Hegel concebe uma unificação espontânea de ambos, a qual evidencia sua identidade originária, algo que impõe também um deslocamento em relação à "compatibilização", tencionada no terreno da possibilidade e do dever-ser do esforço prático, na direção da efetividade do amor, sentida como harmonia da racionalidade com a natureza. "Aquela unificação pode ser denominada unificação do sujeito e do objeto, da liberdade e da natureza, do efetivo e do possível. Se o sujeito conserva a forma do sujeito, e o objeto a forma do objeto, a natureza [permanece] sempre natureza, então nenhuma unificação é encontrada. O sujeito, o ser livre, é o que prepondera, e o objeto, a natureza, é o subjugado" (HEGEL, 1970, 1, 242). É a crítica de Hölderlin a Fichte que é determinante para a refutação de um ideal de subjetividade prática incondicionada que, a

\footnotetext{
${ }^{2}$ Antes mesmo que Hegel atinasse com a possibilidade de afastamento em relação a Kant, Hölderlin formulara, já em 1795, uma crítica da filosofia prática de Fichte como dominação da natureza pela razão, e mesmo do caráter puramente antropológico da ampliação do belo kantiano operada por Schiller (WYLLEMAN, 1989). Para Hegel, é extremamente importante a concepção de um ser (Sein) como unificação (Vereinigung) que antecede o juízo (Urteil) ou a partição originária (Urteilung) que engendra sujeito e objeto. (BONDELI, 1997)
} 
partir do aquém da efetividade consciente, deve se alçar à infinitude pela gradual aniquilação de toda a objetividade, de maneira que se pode reconduzir a unificação da natureza e da liberdade, onde objeto e sujeito são um só sem subordinação, à concepção do Sein explorada por Hölderlin em sua obra-prima Urteil und Sein de 1795 (JAMME, 1990).

Para Hegel, a instituição de uma religião positiva, calcada em uma divindade punitiva, deve-se a uma profunda "separação entre o impulso e a efetividade", em que surge "dor efetiva", contra a qual a religião deve funcionar como meio para obtenção de uma tranqüilização ao menos temporária (HEGEL, 1970, 1, 244). Por outro lado, a religião verdadeira não está nem em um objeto fora do sujeito, o que suscitaria positividade e autoridade, nem em um objeto que está somente no sujeito, o que perverteria o sentido comunitário de uma religião plena. "O ideal nós não podemos pôr fora de nós, senão seria um objeto - [mas também] não somente em nós, senão não seria nenhum ideal.” (HEGEL, 1970, I, 244) Este paradoxo permite que se vislumbre o significado comunitário da concepção hegeliana da unificação (Vereinigung). Hegel pretende que a solução para este dilema esteja numa religião que é "um com o amor" (die Religion ist eins mit der Liebe) (HEGEL, 1970, I, 244).

A religião tem de incorporar a validade comunitária autêntica do amor, para além da dicotomia sujeito e objeto. A religião verdadeira está no sentimento de diversos sujeitos de serem um no amor. O divino, o místico e religioso estão nesta intersubjetividade, nesta comunidade de seres na qual eles perdem o caráter solipsista do indivíduo solitário e vêem-se no outro como objetos, isto é, vêem no outro a si mesmos. O caráter "divino" - e, posteriormente, especulativo, inacessível ao entendimento (HEGEL, 1995, § 426 A) - desta "socialização positiva" - posto que não concerne a seres humanos simplesmente como indivíduos apartados uns dos outros, mas como indivíduos inteiros, estimados, apreciados e plenamente individualizados pela própria "socialização" - , jamais abandonará a filosofia social de Hegel. "A religião é um com o amor (die Religion ist eins mit der Liebe). O ser amado (der Geliebte) não nos é contraposto, ele é um com nossa essência. Nós vemos somente a nós nele; e, contudo, em seguida, novamente ele não é nós - um milagre que não somos capazes de compreender" (HEGEL, 1970, 1, 244). O amor é esta unidade bipolar em que há ausência completa de dominação, em que sujeito e objeto em sentido tradicional não mais estão presentes e se ultrapassa o subjetivismo e 
objetivismo absolutos das sínteses prática e teórica. O amor, enquanto unificação essencialmente bipolar, constitui-se como sentimento de "imanência do divino", o qual se torna efetivo na harmonia consigo mesmo e na suspensão da opressão da natureza própria pela autoridade estranha.

Em oposição à relação comunitária autêntica está a associação interpessoal em vista do que é morto, Liebe um des Toten willen, que corresponde, "subjetivamente", a uma "atitude religiosa" que se liga à projeção do infinito para o supra-sensível enquanto suspensão de toda realidade, isto é, uma compreensão religiosa da relação finito/infinito que se associa ao temor em face de um poder estranho. Já o amor aponta para uma compreensão religiosa da "divindade imanente" à vida social efetiva como experimentação da unicidade da vida. Muito embora a "unicidade da vida", evocando a compreensão hölderliniana do "ser", tenha conotações eminentemente ontológicas, há que se reter certamente o nexo sóciofilosófico do tema. Em face do conceito "contratualista" da sociedade como agregado dos muitos particulares, Hegel antecipa, com seu conceito de amor, aquilo que se tornará seu conceito orgânico de comunidade. "Unificação verdadeira, [o] amor propriamente dito, somente tem lugar entre vivos que se equiparam em poder e são assim completamente / vivos um para o outro, e de nenhuma parte mortos em face do outro ... No amor, este todo não está contido como na soma de muitos particulares, separados" (HEGEL, 1970, 1, 245/246).

A "imanência da divindade" na efetividade social, a "unificação eterna" no amor, impõe que o indivíduo escape ao paradigma da consciênciade-si singular como algo contraposto à infinitude, no qual sua "incondicionalidade" se converte na necessidade relativa em face de um "poder estranho", na condicionalidade do temor em face deste "árido nada" que é o exterior de sua consciência e na obstinação da fé racional na unificação prática (HEGEL, 1970, 1, 245).

Há, entretanto, no distanciamento em relação a Kant, uma renitente ressalva, oriunda da refutação kantiana da metafísica especulativa e que parece aproximar Hegel de Kant durante o período de Frankfurt. O ser supremo não é objeto da filosofia ou do conhecimento, mas apenas da crença e da vivência religiosa: também o amor e o sentimento do ser-um é sempre acometido pelo caráter de sua resistência à reflexão, mesmo de sua inefabilidade. 
Nos Esboços de Frankfurt, Hegel chega, portanto, a uma caracterização comunitária da unificação pelo amor que evidencia também, paralelamente, as diretrizes de sua crítica ao pensamento reflexivo; e, graças a isso, sua noção de unidade comunitária antecipa o teor normativo de uma unidade "em sentido especulativo" . Esta dupla orientação, uma articulação comunitária e especulativa da Vereinigung, aprofunda-se nos fragmentos reunidos sob o título de "Espírito do Cristianismo e seu Destino", os quais consolidam o distanciamento em relação a Kant e Fichte, orientando a delimitação do ponto de vista especulativo que lhe é próprio a partir de Jena: neste sentido, tais fragmentos representam a decantação, sob forte influência de Hölderlin, da intuição de que a reflexão e as oposições introduzidas pela subjetividade são inerentes ao desenvolvimento da vida e ao seu processo de auto-diferenciação.

Ao mesmo tempo - o que já denota o afastamento tendencial em relação a Hölderlin, o qual desqualificava a reflexão, fixada na rigidez da oposição entre o subjetivo e o objetivo, como forma primordial de apreensão do "ser" -, Hegel é conduzido à investigação da relação entre a vida e a reflexão, investigação que tem seu apogeu na crítica da "filosofia da reflexão da subjetividade na totalidade de suas formas"(HEGEL, 1968, GW 4, 315), empreendida em Jena.

\section{Destino e a reconciliação pelo amor: o misticismo da Unificação societária como nadificação do crime}

$\mathrm{Na}$ medida em que se tenciona perseguir nesta parte a articulação comunitária da noção de Vereinigung ainda em Frankfurt, elaborada principalmente em Espírito do Cristianismo, não nos ocuparemos da tentativa hegeliana de ultrapassar a cisão operada pela moral kantiana entre razão e sensibilidade em uma ética do amor (DÜSING, 2004). Interessa-nos aqui, sobretudo, o registro comunitário da unificação enunciada pelo princípio do amor.

Em Espírito do Cristianismo é a discussão sobre virtude que realiza a passagem sistemática do registro individual para o registro social da

\footnotetext{
3 "Ele exclui todas as contraposições, ele não é entendimento, cujas relações deixam o múltiplo sempre como múltiplo, e cuja unidade são as mesmas contraposições. Ele não é razão, que contrapõe pura e simplesmente seu determinar ao determinado. Ele não é nada limitante, nada limitado, nada finito." (HEGEL, 1970, 1, 246)
} 
unificação. Em contraposição à concepção "formalista" de virtude, a qual desemboca, enquanto conflito entre a eticidade e as inclinações, na dominação pelo Selbstzwang, Hegel compreende a virtude como a disposição individual para agir que surge sem dominação ou submissão. "À completa escravidão sob a lei de um senhor estranho contrapôs Jesus não a escravidão parcial sob a própria lei, a auto-coerção da virtude kantiana, mas sim as virtudes sem dominação e sem submissão, modificações do amor.” (HEGEL, 1970, I, 359/360) Mas esta concepção de virtude somente adquire, pela própria exemplificação proposta por Jesus, significado concreto como disposição para um interagir que justamente se pauta pela não dominação do outro, isto é, pelo tratamento do outro não somente como um igual e livre, mas sobretudo como alguém para quem uma exitosa inserção social depende amplamente da participação do sujeito virtuoso.

Pare Hegel, Jesus pretende, com sua concepção de virtude como modificação do amor, retirar dos mandamentos "ama a Deus" e "ama o teu próximo" a própria forma de um mandamento e fundá-los na "inclinação plenamente espiritual do amor". "Sem dúvida, o amor não pode ser ordenado, sem dúvida ele é patológico, uma inclinação - mas com isso nada foi retirado de sua grandeza, ele não é com isso de maneira nenhuma aviltado, que sua essência não é nenhuma dominação sobre algo estranho a ele.” (HEGEL, 1970, I, 362/363) Eis porque Hegel vê como um erro a explicitação, estabelecida na Crítica da Razão Prática e na Tugendlehre, dos mandamentos cristãos que envolvem amor como fundados no respeito ${ }^{4}$. A possibilidade de se retirar destes mandamentos a própria forma do mandamento, isto é, a oposição, intrínseca ao ordenamento moral, entre o universal e o particular, baseia-se, para Hegel, no fato de que o amor não pode ser ordenado sem que sua verdadeira natureza se corrompa ${ }^{5}$. Amor é,

\footnotetext{
4 Para Bondeli, Hegel aderiu à compreensão kantiana da "amizade moral" (Tugendlehre) como unificação de amor e respeito, e a reinterpretou à luz do princípio panteísta do "um em todos e todos em um", mas dirigiu-a contra Kant na forma de uma exigência de auto-superação da obrigação, querendo ver nesta relação um contra-modelo de comunidade capaz de fazer frente a um estado erigido sobre direitos e deveres (BONDELI, 1997, 131)

${ }^{5}$ (HEGEL, 1970, I, 324/325) Aliado à crítica à compreensão kantiana do "dever em amar" está o já mencionado caráter "inefável" do amor, que se interconecta tanto com as exíguas expectativas de Hegel quanto à capacidade da reflexão em fornecer acesso discursivo ao "uno", compreendido na esteira do "ser" da Vereinigungsphilosophie de Hölderlin, cujo acesso privilegiado é, para o Hegel de Frankfurt, ainda a experiência religiosa; quanto com a impossibilidade de que 0 amor venha a ser enunciado como um princípio prático, o que acarretaria em sua fixação no momento conceitual da universalidade e, conseqüentemente, em sua compreensão contraditória como dever (HEGEL, 1970, I, 363).
} 
para Hegel e "seu" Jesus, algo acima daquela oposição que caracteriza a moral, é o sentimento subjetivo e intersubjetivo da unificação, onde as leis não são cumpridas mais por necessitação, mas pela intenção espontânea (Geneigtkeit) em as cumprir: o amor nulifica as oposições entre o universal e o particular, sujeito e objeto, natureza e espírito e, sobretudo, entre o indivíduo e a comunidade, os quais estão numa relação de co-originariedade.

A unificação interior pelo amor supõe sua efetivação na forma de uma intersubjetividade que gera, na percepção de si no outro, o sentimento de si que é esta harmonia entre inclinação e razão no sujeito que age. A conexão dos dois registros é estabelecida justamente pela tentativa de compreender, a partir do amor como unificação, a espiritualidade por trás do mandamento cristão de amor ao próximo. Jesus contrapõe a virtude do amor ao próximo aos mandamentos que supõem um tratamento do mesmo como individualidade abstrata, apartada do sujeito como uma matéria, que lhe cabe apenas dominar, extirpar, servir-se dela ou mesmo deixá-la ir. Neste caso, a separação entre "eu e próximo" se funda na própria compreensão da enunciação de um vínculo ao próximo como mandamento. "Cada mandamento somente pode exprimir um dever-ser, porque é um universal; ele anuncia, ao mesmo tempo, sua incompletude (Mangelhaftigkeit) ao não declarar nenhum ser.” (HEGEL, 1970, I, 327) Portanto, ao invés da obrigação em não fazer mal a outrem (ou mesmo, "não matarás"), Jesus se concentra na disposição do "amor universal à humanidade", que não somente torna supérfluo um mandamento qualquer de respeito ao outro enquanto pessoa apartada, mas, em geral, "suspende o mandamento segundo sua forma, a contraposição do mesmo enquanto o que ordena em face de um resistente, remove aquele pensamento de sacrifício, destruição e submissão (Unterjochung) do ânimo” (HEGEL, 1970, I, 327).

No registro comunitário, a forma da universalidade obrigante, o mandamento, revela-se como a separação completa entre eu e o próximo, a compreensão dele como algo outro que "deve" ser respeitado como pessoa ou indivíduo que é "abstratamente igual” a mim, porém, inteiramente apartado. "E ama teu próximo como a ti mesmo não significa amá-lo tanto quanto a si próprio - pois amar-se a si mesmo é uma expressão sem sentido -, mas antes ama-o como alguém que tu és. Um sentimento da vida igual, não mais poderosa, nem mais fraca. Somente através do amor é quebrado o poder do objetivo, pois através dele todo o âmbito do mesmo rui." (HEGEL, 1970, I, 363) É intrínseca à compreensão do dever em amar o próximo a 
contrapartida de um sujeito como diversidade volitiva resistente ao mandamento, a compreensão do outro como o que "deve extorquir respeito", o significado do outro como o que é, em última instância, "objetivo", apartado, irredutível e que pode ser, nesta medida, dominado, pensado e deve ser respeitado: "Um pensado não pode ser nenhum amado." (HEGEL, 1970, I, 362/363). Por outro lado, o amor é justamente esta consciência da irredutibilidade redutível do outro, "ele conserva a distância entre eu e tu, a insuperabilidade do tu no eu, para ser amor" (SIEP 1979, 44); mas, sobretudo, revela-o como alguém que "eu sou", o sentimento de mim nele, o sentimento da vida igual, que não domina nem é dominada. Com lembra Ludwig Siep, segundo Hegel, a contraparte do amor, o que lhe é mais estranho, não é propriamente o ódio, onde o outro ainda vale como outro, mas antes "considerar o outro como um louco", como um pária, "o que suspende não somente toda relação com ele, mas também toda igualdade, toda comunidade da essência, o subjuga completamente na representação, designa-o como um nada.” (HEGEL, 1970, I, 328)

Esta conexão é responsável pela riqueza do conceito hegeliano de amor, pois evidencia a ambivalência deste processo de completa suspensão da individualidade, cuja contrapartida é a necessária manutenção da diferença e da alteridade do outro. A tentativa de Jesus de retirar do "ama teu próximo" o caráter de mandamento revela que no amor os indivíduos não vêem no ser amado a individualidade diferente, mas antes que o "ser humano se reencontrou a si mesmo no outro.” (HEGEL, 1970, I, 394) Com efeito, por ser este "encontrar-se no outro", este ter o sentimento de si na unificação com o outro, o amor é um impulso para a unificação, para a renúncia de si e, por conseguinte, também separação, cisão da unidade originária entre as duas individualidades.

Para tematizar a articulação comunitária da Vereinigung em Espírito do Cristianismo é necessário compreender como a unificação pelo amor se relaciona ao problema da exclusão do singular. Hegel concebe, a partir da união amorosa, este processo como um resultado da colisão das individualidades e de seu movimento recíproco de auto-afirmação e separação, da ruptura da unidade. Esta unidade, condensada no teor universalmente válido do objeto da inclinação, corresponde à transferência da idéia de harmonia intra-subjetiva para o âmbito intersubjetivo (HEGEL, 1970, I, 363), da cláusula de não dominação do universal sobre o particular e de não resistividade daquele em face deste. "Contudo, por meio disso [de que 
o amor seja uma inclinação] ele está tão pouco abaixo de dever e direito que seu triunfo é muito mais não exercer domínio sobre nada e estar em face de outro sem um poder hostil. $\mathrm{O}$ amor venceu não significa algo como o dever venceu, ele subjugou o inimigo, mas antes ele superou a hostilidade.” (HEGEL, 1970, I, 362/363) O problema é então pensar adequadamente esta expansão da relação intersubjetiva do amor para além dos limites de uma circunvizinhança íntima, do amor universal à humanidade enquanto amor ao próximo, "que deve se estender a todos dos quais não se sabe nada, que não se conhece, com os quais não se está em nenhuma relação” (HEGEL, 1970, I, 362).

Considerada a conexão entre o movimento de auto-afirmação do indivíduo e o ponto de renúncia à individualidade, onde justamente a particularidade da natureza impulsiva entra em harmonia com o espiritual da relação, o processo social de auto-posição da singularidade excludente é referido, por Hegel, à sua gênese no âmbito intersubjetivo da harmonia entre as naturezas pulsionais dos indivíduos, isto é, a um estágio originário de comunicabilidade, cooperação e compartilhamento de interesses ${ }^{6}$. Com efeito, os fenômenos que Hegel compreende como "crime" em Espírito do Cristianismo se referem a uma ruptura da unidade vital do amor, da intersubjetividade cooperativa primária a partir de onde, segundo Hegel, unicamente faz sentido algo como a individualidade excludente. A investigação deste tipo de fenômeno pode evidenciar as condições de possibilidade de retorno à vida reconciliada a partir da cisão proporcionada pela "individualização" em geral.

Hegel aborda tal tema na sua célebre discussão sobre o amor enquanto suspensão do crime, e como reconciliação do criminoso com a unidade vital lesada por seus atos, contraposta à compreensão "legalista" da justiça como pena, uma tentativa de interpretação do tema cristão da remissão dos pecados pela absorção de elementos da tragédia grega e shakespeariana (SIEP, 1976, 45). Tal movimento é a ampliação do "modelo ético” do amor, enquanto harmonia intersubjetiva, até a reconciliação de um

\footnotetext{
${ }^{6}$ Para Habermas, a causalidade do destino, pela qual ele compreende a força de restabelecimento de uma relação ética enquanto "situação não-coagida de diálogo" oprimida pela "violência" que se estabelece entre as partes, é o exemplo originário e paradigmático do que ele chama de "dialética da relação ética", a qual é, segundo ele, reconstruída por Hegel no decorrer do período de Jena sob o título de Kampf um Anerkennung. Para Habermas, esta causalidade é desencadeada pela suspensão "criminosa", isto é, individualista e excludente da relação ética originária, ou seja, da complementaridade da comunicação não coagida e da satisfação recíproca de interesses. (HABERMAS, 1974 791-792)
} 
estágio de dominação institucional da lei, insuficiente para responder pelo vínculo originário entre comunidade e indivíduo. "Porque, a saber, as leis são somente unificações pensadas de contrapostos, então estes conceitos não esgotam, nem de longe, o caráter multifacetado da vida.” (HEGEL, 1970, I, 347)

Vejamos como Hegel compreende a insuficiente integração social, oferecida pela justiça punitiva, da particularidade existente para si do criminoso com a unidade vital. "A lei foi quebrada pelo criminoso, seu conteúdo não é mais para ele, ele o suprimiu. Porém, a forma da lei, a universalidade, o persegue, insinua-se até mesmo em seu crime. Seu ato se torna universal, e o direito que ele suspendeu é também para ele suspenso.” (HEGEL, 1970, I, 338) Trata-se, portanto, de um "re-acolhimento insuficiente" do transgressor na comunidade proposto pelo paradigma "legalista" na forma da pena, a qual "somente executa sua dominação na medida em que a vida chegou à consciência, onde uma separação foi unificada no conceito. Contudo, sobre as relações da vida que não foram dissolvidas, sobre os lados da vida que são unificados e dados vivamente, para além dos limites das virtudes, ela não exerce nenhuma violência.” (HEGEL, 1970, I, 347)

A pena é, para Hegel, enquanto contraposição do indivíduo infrator e do universal transgredido da lei, fixada no momento da identidade abstrata $^{7}$, expansão social da dominação pelo universal vazio da consciência. Assim como no embate intra-subjetivo entre universal e particular, também aqui Hegel argumenta que a identidade abstrata da unificação delito-pena deixa exterior a si o caráter variegado das relações vitais entre indivíduo e comunidade, notadamente os laços originários que estão por trás de "fenômenos" como o perdão e a reconciliação.Hegel ampliara, com seu conceito de positividade, a noção kantiana de heteronomia, passando a compreender, na voz de Jesus Cristo, tanto ela quanto a autonomia moral da

\footnotetext{
${ }^{7}$ Para Hegel, a pena surge como o universal abstrato da lei totalmente apartado do particular, isto é, 0 universal do dever desligado da ação individual (HEGEL, 1970, I, 340). Com efeito, a desobrigação em relação ao universal do dever pressuposta no ato transgressor tem, como contrapartida à existência apartada do universal, a sua irredutibilidade, ou seja, a dependência do indivíduo em relação a ele. A causa disso é, para Hegel, o fato de que, com a transgressão, um dever determinado deixou de ser cumprido, um conteúdo que se subsumia sob lei, mas a forma da mesma, a universalidade permanece intocada, só que agora, enquanto pena, o conteúdo da lei é o próprio ato transgressor. Na passagem da lei à pena, trata-se assim de uma inversão pela qual o conteúdo particular da transgressão se reveste da figura da universalidade da lei, o que reproduz a contraposição entre o particular e universal, agora como pena e transgressor (HEGEL, 1970, I, 340/341).
} 
vontade como formas de uma positividade cujo denominador comum é a "forma legal" da moral e do direito enquanto tal, na medida em que a lei supõe uma contraposição entre o particular e o universal vazio da obrigação. "Lei é uma relação pensada dos objetos uns aos outros; no reino de Deus não pode haver qualquer relação pensada, porque não há quaisquer objetos um para o outro. Uma relação pensada é firme e permanente, sem espírito, um jugo (Joch), um encadeamento (Zusammenkettung), uma dominação e escravidão - atividade e sofrimento (Tätigkeit und Leiden), determinar e serdeterminado.” (HEGEL, 1970, I, 308/309).

O problema para Hegel é mostrar que a culpa não é revogada no "paradigma legalista” da expiação penal ${ }^{8}$, mas permanece eternamente como lesão indelével: a justiça lesada não se reconcilia, o que implicaria na tomada de consciência pelo criminoso da lei como sua própria vontade. "A lei é bem satisfeita por meio disso, pois a contradição entre seu dever-ser pronunciado e a efetividade do criminoso, a exceção que o criminoso quis fazer do universal, está suspensa. Somente o criminoso não está reconciliado com a lei (ela continua sendo para o criminoso um ser estranho ou subjetivo nele, enquanto má consciência)" (HEGEL, 1970, I, 340) Vivificada pelo amor, a lei perdera, para o ser humano virtuoso, seu caráter coercitivo, mas a questão é se, no quadro social de uma justiça institucionalizada, a lei pode perder, na contraposição ao criminoso (HEGEL, 1970, I, 338), seu caráter coercivo de forma geral. "Um juiz pode cessar de agir como um juiz, pode indultar. Mas com isso não se fez bastante à justiça; esta é inflexível, e, enquanto leis forem o mais elevado, não se pode escapar dela, o individual tem de ser sacrificado ao universal, isto é, tem-se que matar.” (HEGEL, 1970, I, 338/339)

Com efeito, onde o crime é visto apenas como violação da lei, a própria pena, ou a investida do universal transgredido sobre o particular criminoso, não pode reconciliar, desfazer o ocorrido. "A lei, enquanto ordenante ou como punitiva, é lei somente através disso: que ela é contraposta ao particular. A lei tem a condição de sua universalidade em que os seres humanos agentes ou as ações são particulares. E as ações são particulares na medida em que elas são consideradas em relação à universalidade, às leis, enquanto conformes ou contrárias a elas ... Elas são o efetivo, elas são o que são. $O$ que aconteceu não pode ser feito não

${ }^{8}$ Acerca da plausibilidade da implícita interpretação hegeliana da concepção "formalista" da pena em Frankfurt enquanto uma radicalização da luta entre razão e sensibilidade, a qual se interconecta com a compreensão da lei moral como Ausführungsprinzip (BONDELI, 1997, 128). 
acontecido, a pena segue o ato.” (HEGEL, 1970, I, 340) A pena é capaz de eliminar insuficientemente a oposição entre a universalidade da lei e a particularidade do criminoso, pois, uma vez que permanece um poder estranho que se ergue contra a exceção pretendida, não é capaz de reconciliar o criminoso com a própria lei, o ser humano com a justiça maculada. "Na má consciência (an dem bösen Gewissen), a consciência de sua ação má, de si mesmo como um mal, a pena sofrida não altera nada. Pois o criminoso vê a si mesmo sempre como criminoso, ele não tem sobre sua ação, enquanto uma efetividade, nenhum poder, e esta sua efetividade está em contradição com sua consciência da lei." (HEGEL, 1970, I, 340)

Vejamos então como Hegel pretende ultrapassar esta exterioridade entre universal e particular. Sua solução é amplamente baseada no conceito de vida. Se a pena consiste no alcance social ampliado da dominação pelo universal abstrato, tal extensão pressupõe o atrelamento da lei ao poder vivo, ao poder da vida comunitária que se volta contra o particular. Para que o criminoso perca seu direito legalmente compreendido "na efetividade ... a lei precisa ser ligada com vivo, ser revestida de poder.” (HEGEL, 1970, I, 338)

A vida é o pressuposto originário da justiça como pena ou do soerguimento do universal lesado totalmente apartado do particular. "Mas o vivo, cujo poder se unificou com a lei, o executor, que retira do criminoso na efetividade o direito perdido no conceito, o juiz não é a justiça abstrata, mas antes um ser (Wesen), e justiça somente sua modificação.” (HEGEL, 1970, I, 338) Mas se é assim, se a justiça em seu exercício, enquanto "modificação de um vivo", somente pode se fazer valer contra o criminoso pela união com a vida, o crime é ele mesmo vida que se contrapõe à vida, ao passo que a lei é vida que se faz valer em sua universalidade contra vida que se particularizou: "vida enquanto vida não é diversa de vida." (HEGEL, 1970, I, 305). O estranhamento entre o universal punitivo e o transgressor é, numa perspectiva originária ${ }^{9}$, o auto-estranhamento da vida, o processo mesmo de sua auto-diferenciação. "Somente através de uma ruptura para fora da vida

\footnotetext{
${ }^{9}$ É bastante ilustrativo notar que, para Hegel, o paradigma da justiça centrado na concepção do destino como pena se constitui como uma esfera originária, a própria vida, a partir da qual, unicamente, a gênese do universal e do particular absolutamente contrapostos obtém sentido (HEGEL, 1970, I, 342). É neste horizonte temático, que antecipa, ainda no registro do conceito de vida e ser da Vereinigungsphilosophie, o poder nadificante da concepção de "eticidade absoluta" no Naturrechtsaufsatz, que Hegel compreende a vida como âmbito anterior e originário do qual a lei surge como "vida incompleta", universal contraposto, incapaz de reconciliar a vida em sua beleza originária (HEGEL, 1970, I, 343/344).
} 
unida (durch ein Herausgehen aus dem einigen Leben), nem regulada pelas leis nem contrária às mesmas, [somente] pela mortificação da vida, é engendrado um estranho. Nadificação da vida não é um não-ser da mesma, mas sua separação, e a nadificação consiste em que ela foi convertida em inimigo.” (HEGEL, 1970, I, 342)

O crime, diz Hegel, "é uma destruição da natureza” (HEGEL, 1970, I, 338). A reconciliação do criminoso com a justiça exige a recondução de ambos à sua unidade vital ${ }^{10}$. Importa, portanto, que o caráter punitivo da justiça não seja absolutizado (HEGEL, 1970, I, 341). "O criminoso pretendia ter a ver apenas com vida estranha, mas ele destruiu apenas sua própria vida; pois vida não é diferente de vida, porque a vida está na divindade concorde (in der einigen Gottheit). Em sua petulância, ele em verdade destruiu, mas somente o caráter amistoso da vida (die Freundlichkeit des Lebens): ele a fez se tornar um inimigo." (HEGEL, 1970, I, 342) Originariamente, portanto, o crime não é apenas transgressão da lei, mas sim violação da existência em comum, ruptura da vida ou da natureza própria (eigne Natur). Esta concepção do crime, que o reconduz às relações vitais entre os indivíduos rompidas por ele, relaciona-se ao universal da vida como destino, isto é, no horizonte do movimento criado pelo anseio da vida cindida de voltar a ser o que era. $\mathrm{Na}$ medida em que a hostilidade intersubjetivamente atingida evidencia a corrupção da cooperação originária, o destino significa o poder ressurgente da vida lesada, impulso de reposição do estofo intersubjetivo que respondia pela comunidade originária de interesses. O re-acolhimento significa que o criminoso passa a sentir a vida lesada como sua própria, percebe seu distanciamento da vida é, na verdade, distanciamento de si mesmo como do apanágio de relações intersubjetivas que formaram sua individualidade. "No destino ... o ser humano conhece sua própria vida, e seu suplicar ao mesmo não é um suplicar a um senhor, mas antes um retornar a si mesmo e um aproximar-se de si mesmo.” (HEGEL, 1970, I, 345) Em uma tal leitura "intersubjetivista" (CRÉAU, 1991), Habermas interpreta a tese hegeliana do anseio pela vida perdida como o reconhecimento pelos

${ }^{10}$ Com essa compreensão, Hegel antecipa sua crítica jenense (Naturrechtsaufsatz) do caráter "arbitrário" e contingente da pena como sanção, como exercício da justiça que mantém a fixação na universalidade abstrata do merecimento da pena. "A necessidade do merecimento da pena permanece firme, mas 0 exercício da justiça não é nada necessário, pois ela, enquanto modificação de um vivo, também pode passar, outra modificação pode entrar em cena. E assim a justiça se torna algo contingente: entre ela enquanto universal, pensado e ela enquanto efetivo, isto é, num ente vivo, pode haver uma contradição." (HEGEL, 1970, I, 339) 
envolvidos de que a contraposição se deve à abstração da conexão vital comum e originária, pelo que fazem a experiência, "na relação dialógica do conhecer-se-no-outro, do fundamento comum de sua existência."(HABERMAS, 1974, 791-792)

Com sua concepção da pena como destino, Hegel pretende justamente compreender o "fenômeno" do crime no horizonte do processo de auto-estranhamento e auto-diferenciação da vida que deságua na reconciliação da vida consigo mesma no amor, pelo que se prenuncia já aqui o mote jenense da cisão como um "fator da vida". "A vida reencontrou a vida no amor. Entre pecado e sua remissão, tampouco entre pecado e pena, imiscui-se um estranho. A vida se cinde consigo mesma e se reunifica." (HEGEL, 1970, I, 354) Eis o (auto-)movimento que permite ultrapassar a compreensão do delito como transgressão, como "acontecer" particular absolutamente apartado da universalidade, e da pena como efetivação social da "insatisfação" do universal transgredido. "O destino é, ao contrário, incorruptível e ilimitado, tal como a vida ... Onde vida foi lesada, mesmo que tenha acontecido também ainda de modo tão jurídico (rechtlich), com tal presunção, aí entra em cena o destino...” (HEGEL, 1970, I, 347) O destino nadifica, enquanto auto-movimento da vida, a absolutização dos lados da oposição e, na medida em que suspende o criminoso como "transgressão personificada" 11 , cria as condições da plena reconciliação: "diante da lei, o criminoso nada mais é do que um criminoso. Entretanto, assim como aquela é um fragmento da natureza humana, assim também este [o é]; se cada uma fosse um todo, um absoluto, então também o criminoso não seria mais do que um criminoso.” (HEGEL, 1970, I, 353)

A auto-posição excludente do singular, a qual poderia ser interpretada como o ponto de vista pressuposto pelas correntes individualistas do direito natural moderno, constitui-se, enquanto originariamente violação da vida em sua unicidade, uma ilusão de óptica. "A enganação do crime, que crê destruir vida estranha e ampliar a si mesmo com isso, dissolve-se quando o espírito deixado para trás da vida lesada entra em cena contra o mesmo." (HEGEL, 1970, I, 342) Diante do destino o indivíduo

11 Segundo Hegel, o retorno do destino enquanto vida em sua hostilidade à totalidade do estado originário é possível em virtude da humanidade total do transgressor, seu vínculo à vida; "pois o pecador é mais do que um pecado existente, um crime que possui personalidade: ele é um ser humano, crime e destino estão nele, ele pode retornar novamente a si mesmo, e quanto ele retorna, / eles estão abaixo dele." (HEGEL, 1970, I, 353/354) 
está, na verdade, não diante de um estranho, mas da força reparadora de sua socialização primeva. "O temor diante da pena é temor diante de um estranho ... a pena pressupõe, portanto, um senhor estranho desta efetividade, e o temor diante da pena é temor diante dele; em contrapartida, o destino é poder hostil, o poder da vida tornada inimiga e, portanto, o temor diante do destino / não [é] o temor ante um estranho.” (HEGEL, 1970, I, 344/345)

Em Geist des Christentums a harmonia comunitária "restaurada" se efetiva como esfera supra-moral e supra-legal, o que evidencia a "vida reconciliada consigo mesma" como uma esfera acima da lei e que a "suspende” em si mesma, um fim imanente à justiça (HEGEL, 1970, I, 340). O amor suspende a contraposição entre indivíduo e comunidade, e os reconduz à "unicidade de consciência" apropriada a este estado de harmonia que Hegel compreende, na linha da Vereinigungsphilosophie de Hölderlin, de maneira panteísta, como o "um em todos e todos em um”. Suspendendo a fixação da oposição no paradigma "legalista" de justiça, o amor fundamenta uma comunidade para além da positividade das leis. Hegel compreende a relação entre amor e justiça como percorrendo a polissemia do verbo aufheben: enquanto uma efetividade espiritual mais elevada, o amor não teria, para se efetivar nas comunidades, de aniquilar as instituições do paradigma "legalista" de justiça, mas antes vivificá-los e, somente desta maneira, pôr-se acima deles e elevá-los a este nível mais espiritualizado de efetividade social. Nesta integração é a tese de que o amor é da lei. "Também na hostilidade do destino é sentida pena justa (gerechte Strafe). Entretanto, como ela não vem de uma lei estranha sobre o ser humano, mas antes, a partir do ser humano, primeiramente surge a lei e o direito do destino, então o retorno ao estado originário, à totalidade é possível...” (HEGEL, 1970, I, 353/354)

A condição "subjetiva" para a possibilidade do retorno da vida a partir da cisão é a percepção do transgressor de seu ato como seu autoisolamento no todo vital, pois nesta consciência de si mesmo como inimigo $^{12}$, consciência de uma auto-exclusão que pressupõe os laços vivos com a comunidade, está já contida a idéia de um impulso ao

\footnotetext{
12 "Então o destino não é nada estranho, tal como a pena ... é a consciência de si mesmo, mas [consciência de si mesmo] enquanto de um inimigo. $O$ todo pode restabelecer dentro de si a amizade, ele pode retornar à sua vida pura através do amor: assim se torna sua consciência novamente crença em si mesmo, a intuição de si mesmo se tornou uma outra e o destino está reconciliado."(HEGEL, 1970, I, 346)
} 
restabelecimento da unidade. “A justiça está apaziguada (befriedigt), pois o criminoso sentiu a mesma vida que ele lesou dentro de si enquanto lesada. Os aguilhões da consciência moral (Gewissen) se tornaram embotados, pois, a partir do ato, o mau espírito deles retrocedeu: não há nada hostil mais no homem.” (HEGEL, 1970, I, 346) Para Hegel, a consciência da unidade perdida é consciência da possibilidade de sua recuperação. A "contraposição é a possibilidade de reunificação, e na medida em que se contrapôs na dor, pode-se ser re-acolhido (wieder aufgenommen [zu] werden). Porque também o hostil é sentido como vida, nisto reside a possibilidade de reconciliação do destino.” (HEGEL, 1970, I, 345)

$\mathrm{Na}$ idéia de que a contraposição traz em seu âmago a possibilidade de reunificação está prefigurada a concepção de dialética como movimento de produção da unidade através da relação dos opostos (SIEP 1979, 48). Aqui ela se revela como consciência do criminoso de seu ato como produção da cisão da vida, em que está imediatamente mergulhado como pressuposto para sua plena reintegração. "O destino é a consciência de si mesmo (não da ação), de si mesmo enquanto um todo, esta consciência do todo refletida, objetivada. Como este todo é um vivo que se lesou, então ele pode mais uma vez retornar à sua vida, ao amor.” (HEGEL, 1970, I, 306) A auto-afirmação excludente dos "transgressores", que os contrapõem no plano social de ação enquanto pessoas, não aparece ainda como elemento constituinte da consciência da unicidade da vida, mas antes como o colapso da mesma, ainda que sob o signo da possibilidade "mística" de sua recuperação.

\section{Unificação e Crítica à Filosofia da Reflexão}

A crítica à moral deontológica se conecta, em Frankfurt, com uma concepção de comunidade como algo que antecede, enquanto elemento "vital", a cisão entre indivíduo e comunidade, tornando possível mesmo obrigações coercíveis. Apesar dos aspectos propriamente "especulativos” deste período (ver o fragmento Glauben und Sein e o Systemfragment von 1800), vinculados ao panorama filosófico pós-kantiano, interessou-nos salientar os aspectos "sócio-filosóficos" da Vereinigung.

Pretende-se agora mostrar que as investigações a que Hegel foi levado pela noção de destino como reunificação da vida, unidade originária de universal e singular, são operacionalizadas em uma crítica da filosofia da reflexão, o que representa o grande marco da "autonomia filosófico- 
sistemática” de Hegel, ainda que sob a inquestionável influência de Schelling. Já o Naturrechtsaufsatz, primeira produção sobre filosofia prática em Jena, vincula-se, em sua crítica ao formalismo do "entendimento prático", à delimitação do ponto de vista especulativo. Entretanto, não podemos pormenorizar a colaboração entre Hegel e Schelling (DÜSING, 1994), ou seu gradual afastamento até Fenomenologia (DÜSING, 1969). Também não é possível refazer aqui o itinerário intelectual de Hegel $^{13}$ até sua revalorização da filosofia como conhecimento do absoluto. Embora o nascimento da filosofia especulativa em Hegel esteja estreitamente ligado à crítica do idealismo kantiano-fichteano, vamos nos eximir de investigar a plausibilidade e fidelidade da mesma ${ }^{14}$. Pretende-se aqui apenas um preâmbulo para ao Naturrechtsaufsatz a partir dos conceitos de entendimento, razão e de sua relação ("teórica" e "histórico-cultural”) ao tema da cisão (Entzweiung), lançando mão da Differenzschrift e de Glauben und Wissen.

Ao absorver o tema da oposição entre consciência pura e efetiva em sua doutrina da gênese das faculdades prática e teórica pelo processo de determinação recíproca do eu e do não-eu, Fichte fornece a Hegel - já em Glauben und Sein, de 1798 - meios para operacionalizar a concepção de Vereinigung em termos da suspensão da separação entre sujeito e objeto. $\mathrm{O}$ que surge daí é, resumidamente, a concepção de Vereinigung fundamental para a crítica "jenense" à "filosofia da reflexão". A moral da autonomia, radicalizada na determinação prática do não-eu pelo eu, não fornece uma unificação sem dominação do objeto pelo sujeito. Sob Vereinigung Hegel compreende uma "concordância" originária destes contrapostos. A partir da

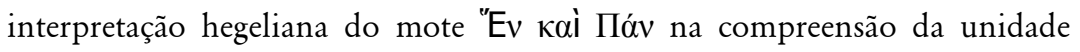
comunitária do amor, da unificação do indivíduo com sua natureza pulsional e com a comunidade, a Vereinigung vai paulatinamente se tornando apta a fundamentar uma crítica especulativa às filosofias de Kant e Fichte como filosofias do dualismo e das oposições fixadas pelo entendimento.

De um ponto de vista histórico-cultural, Hegel compreende que a separação entre o intelectual e o sensível atinge seu ápice na transformação da moderna Reflexionskultur em Reflexionsphilosophie, cuja insuficiência

${ }^{13}$ Referimos o leitor a dois trabalhos, cujo teor e completude parecem aplacar o intento de uma descrição pormenorizada deste desenvolvimento filosófico. (BAUM, 1989) e (GILBERT, 1982)

14 Para uma visualização do diálogo entre Hegel e Fichte, inclusive de suas nuanças recônditas e freqüentemente ignoradas, (SIEP, 1970) 
fundamental reside no impedimento metodológico ao conhecimento do absoluto, o qual Hegel atribui à separação absoluta entre sujeito e objeto. Portanto, a cisão, revelada em oposições epistêmicas irreconciliáveis (universal e particular, espontaneidade e receptividade, conceito e intuição), quando elevada ao elemento conceitual, caracteriza a filosofia da reflexão. Para Hegel, a unificação racional dos termos cindidos e a conseqüente suspensão da diferença irreconciliável entre os opostos passam a ser a tarefa da filosofia. Entretanto, a filosofia da reflexão, objeto de uma crítica para a qual a própria compreensão hegeliana da autêntica filosofia fornece $\mathrm{o}$ critério, é o produto mais sofisticado de uma modernidade calcada no entendimento, trata-se com isso também de uma crítica da modernidade.

Às oposições tipicamente "conceituais", como entre subjetividade e objetividade, descritas na Differenzschrift, corresponde aquela mais cultural, abordada em Glauben und Wissen, entre fé e saber, a qual se origina da luta do esclarecimento contra o obscurantismo que constitui o próprio nascedouro da era moderna. Para Hegel, a finitização do mundo pelo entendimento, que relega o sentimento religioso à interioridade do sujeito, provoca justamente a fuga da religião e da transcendência para fora do âmbito da objetividade, e com isso a dessacralização do mundo (HEGEL, 1968, GW 4, 317 e seg.): tal processo torna qualquer apelo religioso à objetividade, qualquer forma de transcendência ligada ao mundo, obscurantismo e superstição; por outro lado, abre as portas da civilização para a ciência moderna e sua manipulação absoluta do finito como carroschefe da solidificação da Verstandeskultur, bem como para a religião da "beleza subjetiva" (HEGEL, 1968, GW 4, 317, 16). É na prática social desta religião essencialmente subjetiva, cujo acesso à objetividade é vedado pelo entendimento, que Hegel reencontra o tema da perda do poder sóciointegrador intrínseca ao moderno ethos comunitário; pois esta religião, que realça a beleza da pura subjetividade, este produto tipicamente moderno da cultura, não estabelece a comunhão de Deus e do homem, do finito e do infinito, na objetividade social de um culto e no sentimento comunitário da imanência atual da transcendência: ao contrário, a religião moderna - cuja forma típica é, para Hegel, o protestantismo - estabelece a ligação do finito com o absoluto como algo somente subjetivo, que tem que ser fixado nesta 
interioridade e, por isso, "constrói seus altares e templos no coração do indivíduo" (HEGEL, 1968, GW 4, 316/317) ${ }^{15}$.

"A grande forma do espírito do mundo ... que se deu a conhecer nestas filosofias é o princípio do norte e, considerando-o religiosamente, do protestantismo - a subjetividade na qual beleza e verdade se apresentam em sentimentos e disposições, em amor e entendimento."(HEGEL, 1968, GW 4, 316, 33) Esta religião e sua "bela subjetividade" (HEGEL, 1968, GW 4, 319, 34) têm em comum com as filosofias do entendimento - as quais são, justamente por isso, as expressões filosóficas do princípio do protestantismo, da cultura da pura interioridade subjetiva - o impulso infinito em romper as amarras da finitude e se alçar ao além inacessível para o entendimento, reduzido à manipulação da finitude, sem conseguir, no entanto, jamais alcançar este horizonte inscrito em um sujeito concebido contraditoriamente como "absoluto circundado por algo". Entretanto, ao banir a transcendência religiosa para a interioridade subjetiva, o entendimento separa de si mesmo o âmbito da fé, em um movimento que constitui a derrocada do mesmo como razão e de sua capacidade de "ser no absoluto": nega o absoluto como seu conteúdo, permanece apenas no âmbito da finitude e relega todo contato com a infinitude à fé. $\mathrm{O}$ esclarecimento, enquanto processo cultural de formação do espírito moderno evidenciado na querela entre fé e saber (HEGEL, 1968, GW 4, 315), é, com efeito, a derrocada da razão e o abandono da pretensão do saber absoluto.

"A assim chamada crítica das faculdades de conhecimento (Erkenntniskräfte) em Kant, o não sobrevoar da consciência

\footnotetext{
${ }^{15}$ É tentador referir este vínculo entre esclarecimento, protestantismo e a noção de dessacralização ao tópico weberiano do "desencantamento do mundo", desenvolvido em sua "Sociologia da Religião" e em estreita conexão com a relação entre o desenvolvimento do capitalismo no ocidente e a disseminação de modos racionais de conduta de vida associados à ética vocacional do protestantismo ascético. A influência do vínculo estabelecido por Hegel se faz sentir fortemente, também em conexão com uma assimilação profunda da teoria weberiana da racionalização, na formação da "situação de consciência" de onde brota a "Dialética do Esclarecimento" de Horkheimer e Adorno. De fato, para os autores, Hegel conhecia como poucos a dialética do esclarecimento. Não é surpreendente, portanto, que tomem, no ensaio "o conceito do esclarecimento", justamente a perspectiva hegeliana de uma crítica imanente à filosofia kantiana que ressalta a combinação entre dominação da natureza e a abstração (ADORNO, $1985,38)$. Lukàcs mostrou como esta dominação em nível conceitual se ergue como efetiva dominação social, ao indicar que o processo de reificação da consciência, pelo qual a identidade abstrata se torna célula do pensamento burguês, tem como contrapartida a disseminação social da forma mercadoria (LUKÀCS, 1979) Adorno e Horkheimer reafirmam sua dívida com o conceito lukáscsiano de reificação da consciência ao conceberem a abstração identitária da ciência esclarecida como estrutura conceitual fundamental ao valor de troca. (ADORNO, 1985, 25)
} 
em Fichte (das nicht Überfliegen des Bewußtseins) e, em Jacobi, o não empreender nada de impossível para a razão, não significam outra coisa do que limitar absolutamente a razão à forma da finitude e, em todo conhecer racional, não esquecer a absolutidade do sujeito, e fazer da limitação (Beschränktheit) uma lei e ser eternos, tanto em si quanto para a filosofia. Não há nada, portanto, para ver nestas filosofias, além da elevação da cultura da reflexão (Reflexionskultur) a um sistema - uma cultura do entendimento humano comum que se eleva até o pensamento de um universal, [o qual] toma, entretanto, porque permanece entendimento comum, o conceito infinito por pensar absoluto, e deixa seu outro intuir do eterno e seu conceito infinito separados um do outro." (HEGEL, 1968, GW 4, $322 / 323)$

O esclarecimento se comporta negativamente em relação ao conhecimento do absoluto, posto que se mantém no âmbito da finitude e da oposição. Desta maneira, o finito é ele mesmo absolutizado, isto é, é-lhe conferido o status de única realidade possível e efetiva, e o conhecimento, por outro lado, não pode nem se permite ser mais do que um "realismo da finitude" (HEGEL, 1968, GW 4, 321, 38) São "filosofias da subjetividade" ou Reflexionsphilosophien, porque se fixam na subjetividade como ponto de partida e nela permanecem, ou seja, no âmbito da representação da limitação do sujeito em face de um mundo que se lhe contrapõe. A oposição entre fé e saber, levada filosoficamente ao paroxismo da separação entre o "intuir do eterno" e o "conceito infinito", é o ponto de vista para o qual o infinito é o além em relação ao âmbito da finitude, no qual o entendimento chega, pela reflexão, à consciência da limitação do sujeito. Por conseguinte, a transcendência do dualismo não pode ser compreendida como imanência ao finito, mas apenas como o além virtualmente inalcançável vislumbrado pelo sujeito limitado, mas considerado absoluto.

Eis porque Hegel compreende as filosofias da reflexão como "acabamento e idealização" da psicologia empírica, a qual "tinha elevado a primeiro e supremo ponto de vista o ponto de vista de um sujeito ..., e perguntado e respondido o que é o universo, segundo um cálculo razoável, para uma subjetividade que sente e é consciente, ou para uma razão apenas 
afundada na finitude e que se desobriga (sich entschlagende) da intuição e conhecimento do eterno" (HEGEL, 1968, GW 4, 322/323).

$\mathrm{Na}$ medida em que parte da e permanece na interioridade infinita de um sujeito finito, o pendor da filosofia da reflexão é a compreensão do sujeito como o "absoluto subjetivo", a pura igualdade a si do sujeito que pensa e quer. Frente à "psicologia empírica", que remonta a Locke, esta idealização, que torna o sujeito o "conceito infinito", "consiste em que seja conhecido que ao empírico seja simplesmente contraposto o conceito infinito, e que a esfera desta oposição, [oposição entre] um finito e um infinito, seja absoluta (se, no entanto, a infinitude for desta maneira contraposta à finitude, um é tão finito quanto o outro), e que, para além da mesma, além do conceito e do empírico, esteja o eterno, mas faculdade de conhecimento (Erkenntnisvermögen) e razão sejam somente aquela esfera. ” (HEGEL, 1968, GW 4, 323)

O dogmatismo recôndito nesta filosofia é, para Hegel, em geral, a permanência do caráter absoluto da realidade finita decorrente da posição filosófica fixa no sujeito pensante e numa razão encerrada na finitude. As filosofias da reflexão transformaram, para Hegel, o dogmatismo do ser em dogmatismo da subjetividade. Mas se, por um lado, a metafísica do ser se torna uma metafísica da subjetividade (HEGEL, 1968, GW 4, 412, 25) graças à "descoberta" da infinitude e negatividade do sujeito, a fixação na subjetividade pelo processo de formação da identidade abstrata $\mathrm{Eu}=\mathrm{Eu}$ reduz o status que o absoluto tinha no "dogmatismo da substância", para o qual ele funcionara como objeto supremo da razão: o absoluto é agora algo que está além do conhecimento humano. A contraposição se deve ao fato de que o conceito aparece nelas como algo absoluto e, em sua pura abstração, como algo apartado de e contraposto a toda multiplicidade. "Permanece nestas filosofias o ser-absoluto (Absolutsein) do finito e da realidade empírica, e o absoluto estar-contraposto (Entgegengesetztsein) do infinito e do finito, e o idealístico (das Idealische) é compreendido somente enquanto conceito.” (HEGEL, 1968, GW 4, 320, 08)

Porém, Hegel vê expressa nesta filosofia a força da negatividade, compreendida como refutação da cognoscibilidade de tudo que não repouse na esfera da finitude fenomênica empiricamente acessível pelo entendimento. "O que, de outra maneira, valeu como morte da filosofia, que a filosofia deveria renunciar ao seu ser no absoluto, que se excluísse pura e simplesmente dele e apenas se comportasse negativamente para com ele, 
tornou-se doravante o ponto supremo da filosofia, e o nada-ser (Nichtssein) do esclarecimento, pelo tornar-se consciente acerca do mesmo, tornou-se sistema.” (HEGEL, 1968, GW 4, 316) A sofisticação do esclarecimento como filosofia da reflexão consiste apenas em que nesta o entendimento, consciente de si como negatividade da identidade absoluta do sujeito, encontrou seu destino sistemático.

"O procedimento negativo do esclarecimento, cujo lado positivo estava em sua afetação frívola sem conteúdo, proporcionou um [conteúdo] a si mesmo através do fato de que apreendeu (auffasste) sua própria negatividade e, em parte, libertou-se da insipidez pela pureza e pela infinitude do negativo; em parte, entretanto, justamente por isso, somente pode ter como saber positivo igualmente o finito e empírico; o eterno, porém, somente no além." (HEGEL, 1968, GW 4, 316)

Depreende-se daqui o geral da crítica de Hegel a Fichte, que fornece uma realização mais radical da absolutidade do finito ${ }^{16}$. Apesar de enunciar como ponto de partida da filosofia o "conceito infinito", a unidade sujeitoobjeto, permanece na enunciação desta unidade enquanto "conceito", isto é, enquanto o que não se torna também objetivo: "porque a identidade não foi ao mesmo tempo posta no fenômeno, ou seja, a identidade também não passou totalmente para a objetividade, então a própria transcendentalidade é um contraposto, o subjetivo" (HEGEL, 1968, GW 4, 33) Ao estabelecer como fundamento de sua filosofia a infinitude da subjetividade obtida pela abstração do mundo, Fichte torna o princípio da especulação simplesmente a perspectiva de um sujeito individual se opondo ao mundo. Assim, a natureza interior e exterior ao homem são concebidas como algo desprovido de racionalidade, uma coisa oposta ao sujeito e, portanto, como algo que deve ser dominado pelo mesmo. Eis porque, ao comentar a unilateralidade da subjetividade fixada no absoluto ser-contraposto do finito e infinito, Hegel diz:

${ }^{16}$ A dedução das condições tanto do conhecimento teórico, quanto do querer moral a partir da identidade do eu absoluto, é vista por Hegel como um empreendimento circular, pois o eu absoluto nada mais é do que "um momento de espontaneidade e identidade a si de uma consciência constituído por abstração ... A dedução somente acrescenta ao puro momento novamente aquilo que anteriormente fora abstraído." (SIEP, 2000, 41) 
"se este conceito é posto positivamente, permanece somente a identidade relativa possível entre eles, a dominação pelo conceito do que aparece como real e finito, sob o que se encontra todo o belo e ético. Mas se o conceito é posto como negativo, então está presente a subjetividade do indivíduo em forma empírica” (HEGEL, 1968, GW 4, 320)

Prefigura-se aqui a crítica de Hegel ao formalismo do "entendimento prático", a referência ao seu nascedouro na fixação da identidade absoluta subjetiva e na conseqüente separação absoluta entre a razão e a natureza. Entretanto, a riqueza da leitura hegeliana mede-se também pela apropriação crítica. O caráter imprescindível do ponto de vista formalista se mostra ainda no resultado, formulado em Frankfurt, de que a autêntica reconciliação de oposições no absoluto somente é possível quando a negatividade é integrada à vida absoluta. Em Glauben und Wissen, Hegel diz que a "conexão imediata" desta filosofia com a filosofia propriamente dita - conexão que, como lembra oportunamente Hegel, "a filosofia de Jacobi no mais das vezes prescinde" e que está, portanto, formulada em Kant e Fichte -, a conexão com sua posição "verdadeira e positiva, mas subordinada”, resulta justamente do movimento que as constitui: a fixação da identidade subjetiva e contraposição desta à finitude (HEGEL, 1968, GW 4, 413); pois, nesta medida, é "conhecido, nestas filosofias, o pensamento enquanto infinitude e lado negativo do absoluto - [lado] que é a pura nadificação da oposição ou da finitude; mas, ao mesmo tempo, a fonte de todo movimento ou da finitude, o qual é infinito, isto é, que se nadifica eternamente, o nada e a pura noite da infinitude a partir dos quais a verdade se ergue do abismo recôndito, que é o seu nascedouro.” (HEGEL, 1968, GW $4,413)$

Segundo Hegel, a característica fundamental da pura infinitude, "o puro conceito ou a infinitude enquanto o abismo do nada, aonde todo ser imerge" (HEGEL, 1968, GW 4, 413), foi mantida, pela filosofia da reflexão, em seu significado negativo, sem conexão com a "idéia positiva de que o ser não está pura e simplesmente fora do infinito, do eu, do pensar, mas que ambos são um.” (HEGEL, 1968, GW 4, 413) O conhecimento filosófico positivo depende de que seja superado o caráter absoluto da oposição. Isto leva a compreender a negação como momento, lado negativo do absoluto, o 
qual é, enquanto totalidade compreensiva e que abrange a fissura e a negatividade, uma totalidade viva, um todo orgânico no qual negatividade e movimento são "momentos essenciais".

Com efeito, a peculiaridade fundamental do programa jenense é a compreensão de que somente à filosofia cabe conduzir à consciência do poder unificador que é a vida absoluta. Isto implica a "relativização" das oposições da reflexão, evidenciadas na sua gênese a partir da identidade absoluta. Se finito e infinito não podem estar em absoluta contraposição, o ponto de vista do sujeito que reflete sobre seu limite tem de ser assimilado como momento da manifestação da vida infinita, de maneira que a filosofia possa reconstruir conceitualmente o absoluto como "esta unidade sintética originária, isto é, uma unidade que não tem de ser compreendida (begriffen) como produto de contrapostos, mas antes como identidade originária verdadeiramente necessária e absoluta de contrapostos" (HEGEL, 1968, GW 4, 305) A identidade absoluta passa a ser compreendida como o próprio "princípio produtivo" das oposições - de saber e ser, de unidade e multiplicidade, de conceito e intuição, e de sujeito e mundo objetivo - e como "unidade sintética", o termo médio de elementos contrários. A partir de Jena é a filosofia que se orienta pela auto-suspensão da finitude na infinitude: "conhecer o finito é um tal conhecer de uma parte ... mas na idéia finito e infinito são um, e, por isso, a finitude como tal desapareceu, na medida em que ela deveria ter verdade e realidade em si e para si. Contudo, somente aquilo que nela é negação é que foi negado e, assim, posta a verdadeira afirmação.” (HEGEL, 1968, GW 4, 324)

O que se modifica substancialmente em Jena é, portanto, justamente a concepção da verdadeira filosofia. "Suspender estas oposições tornadas firmes é o único interesse da razão. Este seu interesse não tem o sentido de que ela estivesse, em geral, se pondo contra a contraposição e a limitação.” (HEGEL, 1968, GW 4, 13) Se a finitude da consciência não pode ser rechaçada, mas acolhida como momento insuficiente do absoluto, é a própria reflexão que tem de ser mostrada em sua referência positiva à reconstrução conceitual do mesmo: "a reflexão tem, enquanto razão, a relação ao absoluto e ela somente é razão através desta relação; a reflexão aniquila (vernichtet), nesta medida, a si mesma e a todo ser e limitado, ao relacioná-lo ao absoluto. Ao mesmo tempo, no entanto, justamente por sua relação ao absoluto, o limitado tem um subsistir.” (HEGEL, 1968, GW 4, 17) O ponto de vista especulativo supõe a recondução da negatividade da 
reflexão ao absoluto enquanto ambiente em que os contrapostos adquirem subsistência e na qual têm sua origem: "a razão se põe contra a fixação absoluta da cisão pelo entendimento, e tanto mais [se opõe a essa fixação], quanto os opostos absolutos brotaram eles mesmos da razão.” (HEGEL, 1968, GW 4, 14) Portanto, é a própria reflexão que "toma consciência” de si mesma como poder nadificador das oposições que ela própria engendra.

"A razão se apresenta enquanto força do absoluto negativo e, com isso, como negar absoluto - e, ao mesmo tempo, como força da posição (Kraft des Setzens) da totalidade objetiva e subjetiva contrapostas. De uma vez, ela eleva o entendimento acima dele mesmo, impele-o, segundo a maneira dele, a um todo; ela o seduz a produzir uma totalidade objetiva." (HEGEL, 1970, 2, 26) Como "poder aniquilante" e "força da posição", entendimento e razão, negatividade absoluta e positividade absoluta, a razão preenche, enquanto reflexão filosófica, aquela pretensão de Hegel presente desde o Systemfragment: "a vida justamente não pode ser considerada somente como unificação, relação, mas sim tem, ao mesmo tempo, [de ser considerada] como contraposição" (HEGEL, 1970, 1, 422) - e que reaparece na Differenzschrift com a cláusula da cisão como "fator da vida", preenchimento que, juntamente com a transformação da filosofia implicada em sua revalorização frente à religião, constitui o genuíno berço da filosofia especulativa de Hegel. Assim, a reflexão filosófica é reconhecida, ao nível epistemológico, como um lado do conhecimento especulativo, tal como, no âmbito ontológico, a não-identidade obtém seu direito como um lado da realidade absoluta: "pois a cisão necessária é um fator da vida, que se forma eternamente pondo oposições, e a totalidade na suprema vitalidade só é possível através do [seu] restabelecimento a partir da suprema separação (Trennung).” (HEGEL, 1968, GW 4, 13)

Entretanto, há que se mencionar também algo acerca daquilo que distancia o Hegel de Jena da formulação tardia do ponto de vista especulativo, aquilo que justamente tangencia sua aproximação a Schelling e o recurso à noção de intuição intelectual da unidade absoluta. A partir da idéia de que a especulação é o "produzir da consciência desta identidade [absoluta]”(HEGEL, 1968, GW 4, 28), Hegel pretende uma crítica imanente à filosofia da reflexão, com vistas a torná-la fiel ao princípio genuinamente especulativo da unidade absoluta de sujeito e objeto. A reflexão se torna um Instrument des Philosophierens justamente porque permite pensar "especulativamente" cada oposição em face da unidade absoluta. Decomposta 
em suas funções, a especulação é reflexão, mas também intuição transcendental, consciência imediata da unidade de contrapostos, unificação do subjetivo e objetivo. Enquanto auto-suspensão do entendimento, o conhecimento filosófico revela seu lado positivo como intuição transcendental, na qual todas as oposições são nadificadas e a identidade emerge em seu caráter positivo. O ponto-chave para a compreensão de toda a crítica hegeliana a Kant e Fichte durante o período de Jena - e especialmente da crítica ao "formalismo do entendimento prático" - é a noção de um filosofar formal, isto é, aquele que, procedendo sem intuição transcendental da identidade originária e absoluta, permanece enredado em uma oposição irreconciliável entre ser e pensar (HEGEL, 1968, GW 4, 28)

\section{Eticidade absoluta e as condições especulativas para neutralização da exclusão}

Quanto ao desenvolvimento do conceito de comunidade em Hegel, o registro em que operam as mais importantes obras sobre filosofia prática na primeira fase em Jena ${ }^{17}$, o Naturrechtsaufsatz e o System der Sittlichkeit, apresenta-se como um interessante desdobramento da operacionalização do conceito de Vereinigung enquanto crítica da filosofia da reflexão, empreendida nos primeiros escritos críticos desta fase. O objetivo desta parte do trabalho é caracterizar tal desdobramento, em íntima relação com a concepção da pena como destino dos anos de Frankfurt, como a formulação das condições especulativas para uma "nadificação" da auto-exclusão do singular, compreendida agora na perspectiva da moderna exaltação da vida privada.

A concepção do absoluto em voga no Naturrechtsaufsatz é tributária da crítica hegeliana à filosofia da reflexão nos primeiros anos em Jena, mas diferentemente matizada ${ }^{18}$; e isto tanto em virtude da visualização do absoluto ético em seu processo de auto-diferenciação, quanto no que concerne à progressiva adesão à filosofia de Schelling, adesão que não é ainda

\footnotetext{
17 Também Glauben und Wissen e a Differenzschrift apresentam, paralelamente ao embate crítico de Hegel com Kant e Fichte, algumas das teses da filosofia prática de Hegel na primeira fase em Jena. Todavia, mostramos em outra ocasião que o Naturrechtsaufsatz e o System der Sittlichkeit se constituem como uma melhor decantação destas intuições. Ver (LIMA, 2006, 128 e seg.)

18 Para uma consideração pormenorizada das descontinuidades entre a Differenzschrift e 0 Naturrechtsaufsatz, (KIMMERLE, 1970), (HORSTMANN, 1973) e (MEIST, 1980). Especialmente sobre a herança espinosana de Hegel e Schelling, (CRUYSBERGS,1989)
} 
completa na Differenzschrift ou em Glauben und Wissen ${ }^{19}$, mas se aprofunda nos textos de filosofia prática, na forma de um alinhamento mais direto de Hegel com a metafísica espinosana da substância - como expediente para a compreensão da relação comunidade/indivíduo enquanto relação substância/modificações (ILTING, 1974) -, e alcança seu apogeu na utilização do método das potências de Schelling. Tal utilização aparece tanto na gênese da liberdade absoluta no Naturrechtsaufsatz, como na tentativa mais ou menos artificial (SCHNÄDELBACH, 2000, 84) 20 de submeter o desdobramento da comunidade ética ao método de subsunção recíproca de conceito e intuição.

Diante da crítica hegeliana à filosofia da reflexão, o objetivo de "corrigir" o individualismo das modernas teorias do direito natural através do recurso à filosofia política clássica não é uma "restauração" pura e simples do ideal político-comunitário da pólis grega, mas antes a demonstração da negatividade intrínseca à absolutização da liberdade individual e do elemento social em que esta se realiza: a atividade econômica juridicamente regulada. Segundo a tese jenense da "cisão como fator da vida", se a negatividade da esfera de exercício da liberdade individual tem de ser relativizada em face do positivo da plena realização da liberdade na comunidade, isto somente pode ocorrer não pela supressão pura e simples deste momento, mas apenas pela demonstração de seu caráter de momento do todo, um momento ao qual, especialmente em circunstâncias modernas, cabe um devido direito de existência.

Para Hegel, quando considerada apenas sob a perspectiva do singular, em sua manifestação no indivíduo, a eticidade "é posta sob a forma da negação, isto é, ela é a possibilidade do espírito universal, e as propriedades éticas que pertencem ao singular.” (HEGEL, 1968, GW 4, 468)

\footnotetext{
${ }_{19}$ Sobre as principais divergências nas concepções do absoluto em Hegel e Schelling, principalmente naquilo que, nos primeiros anos da estadia de Hegel em Jena, tem sido costumeiramente considerado, desde o século XIX, como uma adesão total, ver (DÜSING, 1969, 1994). Note-se que, ao contrário de Hegel, que concebe, como acesso apropriado ao absoluto, a unidade de reflexão e intuição, Schelling continua a se vincular ao privilégio do acesso pela via da intuição intelectual (SIEP, 2000)

${ }^{20}$ Schnädelbach atribui o caráter fragmentário do System der Sittlichkeit não simplesmente ao caráter inacabado do texto, mas sobretudo à tomada de consciência por parte de Hegel da impossibilidade de utilizar o método das potências de Schelling como princípio de construção da filosofia prática, especialmente na exposição da eticidade absoluta (SCHNÄDELBACH, 2000, 111). Para compreender a concepção hegeliana de intersubjetividade como forjada a partir da assimilação da teoria fichteana do reconhecimento, note-se Honneth, para quem, "ao teor filosófico-social do escrito o procedimento metódico permanece, se acaso eu vejo corretamente, amplamente exterior."(HONNETH, 1992, 33)
} 
Entretanto, seguindo seu programa de uma correção “comunitária” do direito natural moderno, Hegel compreende que a verdadeira natureza da eticidade é "ser um universal ou costumes" (HEGEL, 1968, GW 4, 467), de forma que ela somente se manifesta no singular "na medida em que ela é um universal e o espírito puro de um povo.” (HEGEL, 1968, GW 4, 467) A tese fundamental da política clássica de que "o positivo é, segundo a natureza, anterior ao negativo - ou, como diz Aristóteles, o povo é, segundo a natureza, anterior ao singular" (HEGEL, 1968, GW 4, 467), é evocada no intuito preciso de "contrabalançar" o individualismo e atomismo da compreensão jusnaturalista da associação política.

Com o progressivo destacamento do indivíduo em relação à comunidade - processo que tem início, para Hegel, ainda no império romano, mas se cristaliza com a moderna autonomização, em face da política, da esfera econômica regulada pelo direito privado -, intensifica-se o predomínio do paradigma da justiça, calcado na relação de propriedade e entre proprietários, sobre a organização política. A potência da propriedade privada tem seu fundamento numa relação intersubjetiva limitativa e restritiva que pressupõe singulares completamente formados em sua individualização sem uma referência aos vínculos societários segundo estruturas intersubjetivas "positivas" que, formando um processo originário de socialização, constituem as condições de possibilidade desta individualização. É verdade que somente após alcançar, sob a influência também de Aristóteles (ILTING, 1974), um modelo de desenvolvimento da eticidade, Hegel compreende um processo de socialização que tem como sua contrapartida a individualização. No Naturrechtsaufsatz a ênfase de Hegel está sobretudo no caráter originário do vínculo político dos singulares, de maneira que, "se o singular apartado não é nada independente (nichts Selbständiges), então ele tem de estar, igual a todas as partes, em uma unidade com o todo.” (HEGEL, 1968, GW 4, 467)

Seguindo suas reflexões anteriores, Hegel concebe um vínculo indissociável entre o processo de ruptura da unidade ética originária pela exacerbação do individualismo e a disseminação do paradigma legalista de justiça. A relação intersubjetiva pela qual os indivíduos se contrapõem como sujeitos de direitos dilacera o nexo social que torna possível a imediatez da vida ética no costume e exige, no lugar deste, a integração social pela unidade abstrata e coercitiva da lei: cria-se com isso uma esfera legal que ameaça fazer as vezes de elo unificador da vida social. "Como com o desenvolvimento 
(Wachstum) do indivíduo o todo não avança igualmente, então se separam lei e costume, a unidade viva, a qual conecta os membros, se enfraquece, e, no presente do todo, não há mais qualquer conexão absoluta e necessidade.” (HEGEL, 1968, GW 4, 482) A integração social pela lei toma a feição de uma estrutura desligada da vida, o que implica também a impossibilidade de se explicar o indivíduo na sua inteireza, o que teria de levar em conta sua pertença ética ao todo. "Aqui, portanto, o indivíduo não mais pode ser conhecido a partir de si mesmo, pois sua determinidade é sem vida, a qual a explica e a torna compreensível.” (HEGEL, 1968, GW 4, 482)

Por conseguinte, o conceito hegeliano de absoluto ético tem de possuir uma envergadura capaz de sustentar este projeto. Na introdução ao System der Sittlichkeit, Hegel esclarece que, "para conhecer a idéia da eticidade absoluta, a intuição tem de ser posta perfeitamente adequada ao conceito, pois a idéia nada mais é que a identidade de ambos." (HEGEL, 1968, GW 5, 279) Para que ambos se tornem adequados, explica Hegel, isto é, para "que ... esta equiparação (Gleichsetzen) se torne perfeita”, faz-se necessário que "aquele que aqui fora posto na forma da particularidade tenha de ser posto agora na forma da universalidade, e aquele que fora posto na forma da universalidade tenha agora de ser posto na forma da particularidade" (HEGEL, 1968, GW 5, 279), o que caracteriza a subsunção recíproca de conceito e intuição. Hegel acrescenta que "aquilo que, contudo, é o verdadeiramente absoluto é a intuição, e o verdadeiramente particular o conceito absoluto: cada qual tem, portanto, de ser posto em face do outro uma vez sob a forma da particularidade e outra vez sob a forma da universalidade, subsumindo, primeiro, a intuição sob o conceito, e a outra vez, o conceito sob a intuição" (HEGEL, 1968, GW 5, 279).

Se Hegel pretende que os diversos estágios da eticidade sejam dados a conhecer pela subsunção recíproca de conceito e intuição um sob o outro, tais elementos em seu caráter absoluto constituem, por assim dizer, balizas da exposição, ou seja, "pontos de chegada e de partida"; pois, como diz Hegel, "a idéia da eticidade absoluta é o retomar da realidade absoluta para dentro de si como para dentro de uma unidade (das Zurücknehmen der absoluten Realität in sich als in eine Einheit), de tal forma que esta retomada e esta unidade é a totalidade absoluta" e, portanto, "sua intuição é um povo absoluto, seu conceito é o ser-um (Einssein) absoluto das individualidades.” (HEGEL, 1968, GW 5, 279) 
Por outro lado, se o sistema somente começa a se constituir com a subsunção desta intuição ao conceito, "nesta subsunção, pois, a intuição da eticidade, que é um povo, se torna uma realidade múltipla ou uma individualidade, um ser humano singular" (HEGEL, 1968, GW 5, 280). Ora, tal como, com sua teoria posterior da mediação intersubjetiva da autoconsciência, Hegel reduz a pretensão de absolutidade e universalidade da intuição intelectual fichteana do $\mathrm{Eu}=\mathrm{Eu}$, em face de seu caráter abstrato, ao status de uma consciência singular que se contrapõe ao objeto enquanto desejo (LIMA, 2007, 23); também aqui, no System der Sittlichkeit, Hegel reduz a pretensão do conceito absoluto, cuja fixação sem movimento fornece o fundamento do qual o formalismo do "entendimento prático" pretende deduzir moral e direito como oriundos apenas da razão pura, ao status de perspectiva de um indivíduo singular, de um sujeito particular que se contrapõe ao mundo como ambiente da satisfação imediata ou mediada (pelo trabalho) de suas carências, um singular sobre o qual paira a eticidade como unidade formal (HEGEL, 1968, GW 5, 280).

"A realidade desta representação [que capta a natureza ética apenas a partir do lado de sua identidade relativa E.C.L] se fundamenta na consciência empírica e na experiência universal de cada um de encontrar em si mesmo ... esta unidade pura da razão prática ou a abstração do eu.” (HEGEL, 1968, GW 4, 434) A crítica ao formalismo do "entendimento prático", enquanto preâmbulo para o delineamento da auto-diferenciação do absoluto ético (MÜLLER, 2003), pode ser compreendida justamente como absorção do conceito absoluto na intuição absoluta enquanto momento da mesma. Para Hegel, a conseqüência prática mais importante da fixação formalista no momento subjetivo da liberdade é dupla. No aspecto prático-moral desta fixação, a perspectiva do indivíduo e do sujeito autônomo torna-se o ponto de partida dos "sistemas da comunidade humana". "Esta liberdade não se encontra a si mesma enquanto razão, mas sim enquanto ser racional, isto é, sintetizado com seu contraposto, com um finito, e já esta síntese da personalidade encerra em si a limitação de um dos fatores ideais, como aqui é a liberdade. Razão e liberdade enquanto ser racional não são mais razão e liberdade, mas um singular.” (HEGEL, 1968, GW 4, 54)

Com efeito, se, por um lado, o formalismo na compreensão da liberdade transforma a perspectiva genuinamente racional da liberdade efetivada em relações intersubjetivas - e, em última instância, na organicidade do povo - numa "eticidade do singular" (HEGEL, 1968, GW 4, 467); por 
outro lado, somente permite a compreensão da comunidade política como um agregado de indivíduos autônomos sob a autoridade juridicamente constituída, de átomos subsistentes por si concebidos, de acordo com premissas atomistas e individualistas do contratualismo, como anteriores à sua associação ${ }^{21}$, o que também se revelará, como mostrarão o System der Sittlickeit e os Jenaer Systementwürfe, uma compreensão da comunidade política que despreza as condições de socialização humana no forjamento da identidade intersubjetivamente mediada dos indivíduos.

A argumentação possui então dois momentos: o primeiro, propriamente crítico, pretende mostrar como a fixação no conceito absoluto é incapaz de compreender a eticidade. No segundo momento, no quadro geral da idéia de eticidade absoluta, o princípio do conceito absoluto é reduzido em sua pretensão de universalidade e compreendido como o ponto de vista da singularidade e, como tal, como perspectiva que, compreendida isoladamente, é o ponto de vista da Unsittlichkeit22. "Não se pode também falar em negar este ponto de vista ... Mas isto tem de ser afirmado: que ele não é o ponto de vista absoluto, como aquele no qual, conforme foi mostrado, a relação se prova somente como um lado, e o isolar da mesma, [prova-se], portanto, como algo unilateral, e que, porque eticidade é algo absoluto, aquele ponto de vista não é o ponto de vista da eticidade, mas antes que nele não há qualquer eticidade.” (HEGEL, 1968, GW 4, 434) A peculiaridade da crítica de Hegel está na compreensão de que este ponto de vista, enquanto perspectiva do singular, tem de ser integrado como momento da própria eticidade. "A consciência empírica é empírica porque os momentos do absoluto aparecem nela dispersos, contíguos, em seqüência, apartados. Mas não seria ela mesma nenhuma consciência comum, se a eticidade não aparecesse nela igualmente.” (HEGEL, 1968, GW 4, 434)

Enquanto a eticidade é algo absoluto, somente sua autodiferenciação pode conferir valor ético à perspectiva do conceito absoluto,

21 "Esta substancialidade absoluta dos pontos funda um sistema da atomística da filosofia prática, no qual, assim como na atomística da natureza, um entendimento estranho aos átomos se torna lei, a qual, no prático, se chama direito, um conceito da totalidade que deve se contrapor a cada ação - pois cada qual é uma [ação] determinada - determiná-la e [deve], portanto, matar nela o vivo, a verdadeira identidade." (HEGEL, 1968, GW 4, 58)

22 "E o que diz respeito ao recurso à consciência comum, então, justamente na própria, a eticidade tem de aparecer necessariamente da mesma maneira como aquele ponto de vista, o qual, já que a relação se isola para si, enquanto sendo em si e que não é posto enquanto momento, é o princípio da nãoeticidade." (HEGEL, 1968, GW 4, 434) 
extirpando, ao romper seu isolamento, o risco da não-eticidade ou do individualismo incapaz de apreender a anterioridade dos vínculos intersubjetivos em relação à pressuposição das singularidades autonomizadas. Com efeito, a eticidade em seu caráter genuinamente absoluto, em sua substancialidade e em seu movimento de produção das determinidades, somente pode ser apreendida ao se recorrer à intuição, a faculdade que Hegel identificou, na Differenzschrift, com o poder racional de nadificar as determinações da reflexão. Frente ao proceder diferenciador da reflexão, "a unidade da intuição ... é a indiferença das determinidades, as quais constituem um todo, não um fixar das mesmas enquanto apartadas ou contrapostas,/ mas antes um apreender em conjunto (Zusammenfassen) e objetivar das mesmas" (HEGEL, 1968, GW 4, 439/440). Nesta "presença absoluta", propiciada pela intuição, na qual "indiferença e as determinidades diferentes são pura e simplesmente unificadas”, "jaz a força da eticidade em geral e, naturalmente, também da eticidade em particular, de que se trata primeiramente para aquela razão legislante e da qual, antes, justamente aquela forma do conceito, da unidade formal e da universalidade tem de ser afastada; pois esta é justamente aquilo pelo que a essência da eticidade é imediatamente suspensa.” (HEGEL, 1968, GW 4, 439) Para Hegel, é justamente na oposição irredutível - tanto da razão prática à natureza pulsional, quanto da vontade universal às vontades singulares - que reside a ameaça não-ética (unsittlich) do formalismo, pelo que o universalmente necessário se converte, pela irredutibilidade do outro como oposto, em algo contingente.

No Naturrechtsaufsatz, Hegel concebe o absoluto especificamente como unidade absoluta, isto é, como unidade à qual não basta o caráter "relativo" de uma unidade em contraposição ao seu oposto, a multiplicidade, mas que a abarca. Nestes termos, a unidade absoluta é compreendida como identidade de unidade e multiplicidade. A condição para esta identidade está em que ambas, unidade e multiplicidade, possuam determinidades apenas ideais e relativas, isto é, determinidades cujas realidades não sejam independentes ${ }^{23}$. Desta maneira, tanto a unidade como a multiplicidade tem

23 "O absoluto é conhecido, segundo sua idéia, enquanto esta identidade de diferentes, cuja determinidade é serem um deles a unidade, e o outro a multiplicidade; e esta determinidade é ideal, isto é, ela é apenas na infinitude ... esta determinidade é suspensa na exata medida em que é posta. Cada qual, tanto a unidade quanto a multiplicidade, cuja identidade é o absoluto, é ela mesma unidade do uno e do múltiplo." (HEGEL, 1968, GW 4, 432) 
de ser compreendida como unidade de unidade e multiplicidade, de modo que a distinção entre ambas estaria no fato de que, enquanto unidade, os opostos são postos como negados, ao passo que, enquanto multiplicidade (unidade de unidade e multiplicidade), os contrapostos aparecem como existentes. O absoluto no Naturrechtsaufsatz descreve, então, um movimento que passa por três momentos. Primeiro, enquanto unidade de multiplicidade e unidade posta como unidade, isto é, como suspensão da diferença entre os termos, o absoluto está no momento da indiferença. Enquanto multiplicidade que é unidade de uno e múltiplo na qual ambos possuem existência real em sua diferença e constituem, por isso, uma unidade relativa, o absoluto está, segundo Hegel, no momento da relação (Verhältnis).

Esta unidade relativa, em que os contrapostos aparecem como entidades em face um do outro, manifesta-se, para Hegel, de duas maneiras, as quais perfazem os dois momentos do absoluto em relação: ou a unidade determina a multiplicidade, de maneira que esta é posta para ser negada; ou a multiplicidade é dominante, e é a unidade que é posta para ser negada. Deste modo, a totalidade positiva no Naturrechtsaufsatz é o movimento que abrange a indiferença ou unidade absolutamente negativa e a unidade positiva da relação em suas duas manifestações. "Já que esta relação bilateral recai sobre a multiplicidade, e se nós chamarmos de indiferença a unidade dos diferentes, a qual se encontra do outro lado e na qual aquela realidade ou o múltiplo está suspenso, então o absoluto é unidade da indiferença e da relação (Einheit der Indifferenz und des Verhältnisses)" (HEGEL, 1968, GW $4,433)$

O absoluto é compreendido em sua essência como indiferença, com a qual, entretanto, enquanto negação de toda diferença, é posta imediatamente a existência da diferença. "A substância é absoluta e infinita. Neste predicado infinitude está contida a necessidade da natureza divina ou o aparecimento dela, e esta necessidade se expressa como realidade justamente numa dupla relação.” (HEGEL, 1968, GW 4, 433) Para que o absoluto seja esta negação de toda a diferença, tem de aparecer como esta unidade, o que implica que seja posta como sendo em face de seu outro, a multiplicidade. Com efeito, Hegel compreende o duplo momento relacional do absoluto, a identidade relativa dos opostos que implica sua contraposição, como o momento do aparecimento, do manifestar-se do absoluto, o aparecer de sua essência indiferente. "Esta relação (Verhältnis) bilateral determina o duplo lado da necessidade ou do aparecimento do absoluto.” (HEGEL, 1968, GW 4, 
433) Enquanto essência que tem necessariamente que aparecer, o absoluto é o movimento de posição da oposição a partir da indiferença e de retorno a si pela suspensão da diferença em seu momento originário.

Antecipando os caracteres gerais de sua crítica ao formalismo como filosofia prática, Hegel atribui ao momento da unidade ou da liberdade ${ }^{24}$ na esfera relacional do aparecimento do absoluto o caráter de infinitude, unidade pura que se opõe à multiplicidade finita enquanto sua absoluta negação. "Este contraposto real é, de um lado, o ser múltiplo ou a finitude e, contraposta a ela, a infinitude enquanto negação da multiplicidade (Vielheit) e, positivamente, enquanto pura unidade. E o conceito absoluto, constituído desta maneira, fornece nesta unidade o que é denominado de razão pura." (HEGEL, 1968, GW 4, 431) A crítica hegeliana ao formalismo se baseará na refutação da pretensão que se arroga esta infinitude de ser absoluta, enquanto permanece apenas o puro movimento de negatividade e de abstração, incapaz de negar a existência de seu oposto enquanto oposto: "ela é o princípio do movimento e da alteração, então sua essência mesma não é nada além do que ser o contrário imediatizado de si mesma, ou seja, ela é o absolutamente negativo, a abstração da forma, a qual, sendo ela identidade pura, [é] imediatamente pura não-identidade ou absoluta contraposição" (HEGEL, 1968, GW 4, 431). Enquanto princípio de movimento e mudança, a infinitude absoluta é, presa à afirmação sub-reptícia do seu oposto, a conversão na absoluta finitude, na oposição absoluta, na absoluta determinidade. Se, por um lado, a infinitude não pode ser desvinculada do seu oposto, a verdadeira infinitude é, para Hegel, positiva, a unidade absoluta de si mesma e de seu oposto. Por isso mesmo, a infinitude pura pertence, enquanto momento, ao aparecer do absoluto; entretanto, enquanto simples momento, está restrita àquela esfera em que a unidade ou a liberdade se põe a si mesma como contraposta à multiplicidade e à necessidade, a esfera de uma relação de exterioridade e determinação recíproca que é tão essencial quanto o momento da indiferença ou da unidade interior dos termos.

\footnotetext{
${ }^{24} \mathrm{Na}$ manifestação do absoluto como natureza ética, são distinguidos então o momento da indiferença ou da liberdade absoluta e o momento do exercício da liberdade sobre o domínio da necessidade, de forma que a natureza ética é livre também em termos relativos, isto é, na esfera da necessidade, e a eticidade é o reino da liberdade que se realiza a si mesma. "Porque, entretanto, na natureza ética, mesmo em sua relação, a unidade é o primeiro, então / ela é, também nesta identidade relativa, isto é, na necessidade, livre." (HEGEL, 1968, GW 4, 433)
} 
Para Hegel, o direito natural de Fichte é a expressão melhor acabada do formalismo no direito natural e, de certa forma, também o registro teórico para o qual converge a tradição do direito natural moderno como um todo. Este formalismo se baseia na "abstração nula (die nichtige Abstraktion) do conceito da liberdade universal de todos, que estaria separada da liberdade do singular, enquanto que, do outro lado, justamente esta liberdade do singular [estaria] igualmente isolada. Cada qual posto para si é um abstração sem realidade.” (HEGEL, 1968, GW 4, 446) A relação de coerção, através da qual Fichte espera unificar as vontades singulares e a vontade universal e tornar possível a vida em comunidade, implica, primeiramente, a expectativa contraditória de que "a liberdade do singular seja conforme ao conceito da liberdade universal pela exterioridade da coerção", isto é, de que "o singular seja absolutamente igual ao universal através de algo não absoluto.” (HEGEL, 1968, GW 4, 446) Em segundo lugar, ela implica a concepção dos "sujeitos da eticidade" como uma multidão de seres dotados de arbítrio, vontades singulares passíveis de serem determinadas por um universal exterior às mesmas, os quais, por sua vez, somente se relacionam uns aos outros de maneira negativa, como átomos cujas esferas de ação são determinadas como coerção recíproca.

Contra a concepção do universal como exterior às vontades singulares, uma compreensão de sua unidade interior e originária - pelo que, segundo Hegel, tais conceitos enquanto "absolutamente idênticos" e "postos meramente nesta primeira identidade que jaz como fundamento", seriam completamente diferentes "do que aqueles conceitos, os quais têm seu significado apenas na não-identidade” (HEGEL, 1968, GW 4, 446) -, o direito natural que se baseia nesta relação intersubjetiva implicada na relação de coerção entre universal e singular, constitui, para Hegel, uma hipertrofia do alcance do modelo interpessoal do direito privado e das relações contratuais de direito civil, uma penetração (eindrigen) ilegítima desta relação na "majestade absoluta da totalidade ética". "O elemento principal aqui no foco da crítica hegeliana [ao contratualismo] é o da construção da unidade ética a partir de liberdades individuais, concebidas numa multiplicidade posta como originária, e que fundam sua coexistência mediante um acordo de limitação recíproca dos arbítrios segundo uma lei jurídica que implica um poder coercitivo.” (MÜLLER, 2003, 63) Desta maneira, se a relação de coerção se atrela à racionalidade própria ao intercâmbio jurídico dos indivíduos e à manutenção da ordem legal de sua existência comum, revelar esta relação 
como um momento do movimento do absoluto, que se põe a si mesmo como totalidade ética, é mostrar a origem derivada desta relação e, nesta medida, subtrair-lhe a pretensão de esgotar a compreensão filosófica da comunidade política ${ }^{25}$.

"O momento do negativamente absoluto ou da infinitude ... é momento do próprio absoluto e tem de ser mostrado na eticidade absoluta" (HEGEL, 1968, GW 4, 449) Para operar esta crítica do jusnaturalismo contratualista na forma de uma "remissão" do momento relacional ao movimento pelo qual a indiferença "aparece" nesta relação, Hegel postula ${ }^{26}$, no Naturrechtsaufsatz, que a eticidade absoluta, o aparecimento do absoluto prático como natureza ética, cuja essência é a indiferença entre universal e particular, é realizada positivamente como povo. "Como aqui importa [que] o lado da infinitude tem de ser salientado, então pressupomos aqui o positivo, [pressupomos] que a totalidade ética absoluta nada mais é do que um povo, o que se fará claro também já no negativo" (HEGEL, 1968, GW 4, 449). O fato de que Hegel não explore as razões que sustentam sua asserção e pareça aqui proceder dogmaticamente, conecta-se com o sentido programático do texto. No Naturrechtsaufsatz, Hegel não pretende construir um sistema da eticidade, mas antes oferecer uma crítica do jusnaturalismo, delimitando ou salientando o valor ético da infinitude e do negativo na organização da totalidade ética, tornando clara sua asserção pelo menos do lado do negativo; e, para isso, assume que o absoluto tem sempre de se manifestar numa configuração concreta. Ao declarar que o povo é a configuração concreta na qual a eticidade absoluta é efetivada, Hegel compreende como tarefa do direito natural especulativo suprir a carência da compreensão jusnaturalista que se mantém na exterioridade mútua entre universal e particular, e mostrar que tanto o momento da indiferença de unidade e multiplicidade, quanto o momento da relação em sua identidade relativa se concretizam no horizonte da existência ética comunitária como povo.

Seguindo este programa, Hegel compreende o momento da indiferença como a identidade originária entre os indivíduos no povo, pretendendo entender aqui não uma unidade exterior, mas antes que o povo

\footnotetext{
${ }^{25} \operatorname{Ver}($ MÜLLER, 2003, 66) e (SCHNÄDELBACH, 2000, 37)

${ }^{26}$ Apoiado em Scnädelbach, Müller compreende aqui um momento que, nos limites do artigo de 1802/03, permanece uma pressuposição dogmática de que a totalidade ética, ou o povo, seja 0 aparecimento do absoluto prático, o momento positivo do absoluto compreendido como identidade de indiferença e relação (MÜLLER, 2003, 45) e (SCHNÄDELBACH, 2000, 33)
} 
mesmo se constitui originariamente pelo fato de que todos os indivíduos pertencem indiferentemente a ele, de que ele constitui seu "espírito". É no momento da relação que o povo e os indivíduos estabelecem entre si uma oposição, e também uma identidade que é, por isso, não mais que formal ou relativa. A tese fundamental de Hegel é, pois, que a relação entre universal e singular, entre povo e indivíduos, somente é eticamente significativa se referida à indiferença, de maneira que a identidade originária se sobrepõe absolutamente àquela unificação dos indivíduos em que predomina a universalidade exterior. Esta sobreposição absoluta é a negação dos indivíduos em sua finitude, não somente uma negação de uma determinidade singular (por meio de coerção), mas a negação da totalidade de suas determinações, a fortiori de suas vidas. Somente a referência da unidade relativa à indiferença pode, na forma da nulidade do indivíduo enquanto oposto ao povo, fornecer uma compreensão da infinitude verdadeira. Hegel descreve então um $\operatorname{arco}^{27}$ que vai desde a indiferença negativa - a indeterminidade da vontade como arbítrio, que se limita ao acolhimento de um conteúdo empírico como princípio subjetivo em detrimento do que permanece necessariamente exterior a este conteúdo -, até a indiferença positiva, ou seja, a integração da totalidade de determinidades que constituem a existência do singular numa totalidade comunitária orgânica, pelo que recebem seu significado ético: a existência ética positiva do singular como membro do todo.

\section{social \\ 5. Eticidade e Justiça Vingativa: negatividade e intensificação do nexo}

Nesta última parte, pretende-se mostrar como a articulação especulativa da noção hegeliana do universal comunitário, atingida no Naturrechtsaufsatz, permite uma revisitação de sua tese, formulada em Espírito do Cristianismo, de que a capacidade do universal da vida ética de nadificar a auto-posição excludente do singular, neutralizando e re-acolhendo esta "exclusão", constitui a força de intensificação dos laços comunitários. Entretanto, o peculiar desta reformulação no System der Sittlichkeit é a ausência do recurso ao misticismo cristão da remissão dos pecados e da reconciliação e uma estruturação especulativa da própria noção de eticidade.

27 Para uma análise pormenorizada deste arco, ver (MÜLLER, 2003, 52 a 55) 
No System der Sittlichkeit, o princípio da eticidade em relação, como Hegel compreende as duas primeiras divisões da obra, é a singularidade, de maneira que toda forma de indiferença é, ao fim e ao cabo, sempre a subsunção sob uma universalidade formal. "O que foi visto até aqui tem a singularidade por princípio. $\mathrm{O}$ absoluto está subsumido sob o conceito, e todas as potências exprimem determinidades, e as indiferenças são formais, universalidade que se contrapõe à particularidade.” (HEGEL, 1968, GW 5, 309) Já a parte sobre o crime expõe a ampliação gradativamente mais abrangente do universal através da assimilação de posições do singular que revelam abstrações progressivamente mais intensas ${ }^{28}$. Trata-se, portanto, da construção de níveis de alcance social de um universal que se comporta ainda de maneira negativa ${ }^{29}$. "Agora a forma é, enquanto negativo, a essência. O real é posto como ideal, é determinado pela liberdade pura.” (HEGEL, 1968, GW 5, 310)

Desde suas discussões sobre intersubjetividade em Frankfurt, Hegel caracteriza a "modernização" como sistemático destacamento do indivíduo das relações éticas em que está desde sempre enredado. Hegel enxerga em Fichte, por outro lado, o extremo da tentativa de fundamentar a posição absoluta do indivíduo e de um sistema do direito enquanto limitação recíproca das liberdades (LIMA, 2006(b), 23). Fichte localiza a origem da relação de direito no movimento de gênese da autoconsciência, isto é, da identidade individual: em sua Nova Methodo, o processo de gênese da autoconsciência é a "passagem da indeterminidade à determinidade" 30 , isto é, a transformação da pura espontaneidade em consciência limitada, de maneira

\footnotetext{
${ }^{28}$ Neste sentido, o crime se reverte, graças à sua estrutura da negação abstrata, no asseguramento de uma universalidade mecânica e sem vida, um desenvolvimento quantitativo do universal das determinações sociais. 0 universal da existência comunitária é ampliado proporcionalmente aos fenômenos assimilados pelo seu restabelecimento. No ápice do desenvolvimento, a indiferença da vida pré-estatal, a família, é despida, na guerra, da determinação singular e ampliada a uma unidade quantitativamente mais abrangente e mais formal: vê-se assim que a assimilação do crime intensifica a universalidade em sua abrangência e alcance social.

29 Uma compreensão da real função do segundo capitulo do System der Sittlichkeit parece extrapolar realmente o escopo metodológico imposto pela tentativa de reconstruir o ético através da Potenzenmethode. As indicações de Hegel quanto o direcionamento lógico pelo conceito e pela abstração do universal formal parecem privilegiar a interpretação segundo a qual a parte sobre o crime se insere no estágio geral de subsunção sob o conceito, a qual já é operacionalizada na eticidade natural (GÖHLER, 1974, 393)

30 "Toda consciência da auto-atividade (Selbsttätigkeit) é uma consciência do nosso limitar de nossa atividade. Mas eu não posso intuir a mim mesmo como limitante sem pôr um passar da indeterminidade à determinidade e contrapô-lo ao determinado."Zweite Einleitung, AA IV, 2 (34)
} 
que o direito, concebido segundo o modelo da limitação recíproca das liberdades, é o limite à liberdade ilimitada do indivíduo (LIMA, 2006(a), 28 e seg). É este conceito de liberdade ilimitada, que se põe em absoluta oposição e negatividade, que Hegel aborda no segundo tomo de System der Sittlichkeit, sobre "a liberdade ou o negativo ou o crime"31. "Este negativo ou a liberdade pura se dirige então à suspensão do ob/jetivo de tal maneira que ele torna a determinidade ideal, somente exterior e superficial na necessidade, o negativo em essência e, portanto, nega a realidade em sua determinidade, mas fixa esta negação" (HEGEL, 1968, GW 5, 310/311).

O crime representa a primeira tentativa de suspender a oposição entre universalidade e particularidade. A falha do crime na realização da unidade está em que a negação é um ato do indivíduo, apoiado na posição da singularidade. Neste sentido, o crime é uma tentativa de suspender a oposição cuja unilateralidade reside no caráter exclusivamente negativo: a pretensa auto-remoção do singular da eticidade se revela como idealidade da posição do sujeito singular, reiterando a oposição. Assim, o objetivo da parte central do System der Sittlichkeit se inscreve na seguinte diretriz: se a indiferença absoluta e a totalidade devem ser plenamente reconstruídas, a universalidade, desenvolvida em estruturas societárias pré-políticas, tem de ser ultrapassada em sua deficiência. Para articular esta diretriz, que inclui tanto o escopo do capítulo central quanto sua plena resolução na parte final do texto, Hegel se serve de uma dissemia do termo aufheben. "A eticidade absoluta se eleva para além da determinidade através disso: que o negativo a suspende, mas de tal maneira que ele a unifica, em algo mais elevado, com o contraposto dela” (HEGEL, 1968, GW 5, 310).

Segundo o sentido mais profundo e decisivo do "suspender", a “suspensão negativa”, que é, segundo Hegel, "suspensão contra suspensão, contraposição contra contraposição” (HEGEL, 1968, GW 5, 310), as determinidades societárias são negadas em sua renitente singularidade, unificadas com seu oposto e elevadas à eticidade verdadeira, mas não ao preço de que o finito determinado perca nela seu subsistir: "a idealidade, a

\footnotetext{
${ }^{31}$ Não estamos aqui contestando a já amiúde aludida influência de Hobbes sobre o segundo capítulo do System der Sittlichkeit. Segundo Siep, a questão não é tanto o conceito de "luta de todos contra todos", mas antes o enunciado, vinculado à teoria hobbesiana do estado de natureza, de que a liberdade ilimitada do indivíduo, concebida por Hobbes como "direito de todos a tudo" e por Fichte como Urrecht, expressa-se no ambiente de conflito ou de luta. (SIEP, 1974) Hegel compreende a liberdade ilimitada não como a liberdade singular própria à compreensão do estado de natureza em Hobbes, mas como negação da eticidade natural e de seus níveis de interação.
} 
forma subsiste nela igualmente, porém em sentido invertido ... ela mantém firme o ser-determinado ideal da singularidade e o determina assim como um negativo; [de tal maneira], portanto, que deixa subsistir sua singularidade e seu ser-contraposto, não suspende a oposição, mas antes transforma a forma real em ideal." (HEGEL, 1968, GW 5, 310) Neste sentido, o que resulta desta "dupla suspensão", que "deixa em verdade [o contraposto] subsistir e o põe apenas em sentido negativo" (HEGEL, 1968, GW 5, 310), é não a aniquilação do real pela assimilação ao ideal, mas a transformação do mesmo em idealidade.

O capítulo sobre o crime se estrutura, por outro lado, segundo uma suspensão simplesmente negativa, através da qual a determinidade finita, sem alcançar um pleno re-acolhimento na totalidade, desaparece, subsumida ao momento ideal do absoluto, o que só serve à reiteração de uma incontornável oposição. Sua insuficiência distintiva, em face à eticidade absoluta, está em que esta

\begin{abstract}
"se eleva acima da determinidade ao suspendê-lo [o negativo E.C.L], mas de tal maneira que o unifica com seu contraposto em uma unidade mais elevada. Portanto, não o deixa, em verdade, subsistir, nem o põe somente em significado negativo, mas antes, através da identidade plenamente acabada como o seu contrário, suspende a sua forma ou idealidade, toma-lhe justamente o negativo e o torna absolutamente positivo ou real” (HEGEL, 1968, GW 5, 310).
\end{abstract}

Em contrapartida, portanto, trata-se, com o crime, de um movimento no qual as determinidades societárias pré-estatais são negadas em seu próprio "estágio ético", isto é, têm seu caráter de uma universalidade social ainda determinada pela oposição ameaçada pela contraposição radical à singularidade: a realidade essencial do oposto não é atingida, pelo que se ratifica a idealidade da determinidade ao custo de sua realidade. Eis porque aquela suspensão total desemboca na eticidade absoluta, enquanto esta suspensão ainda "inacabada" é tematizada num estágio ético relativo em que o singular se opõe às formas originárias de intersubjetividade. A interdependência destas formas de negação reside em que a acolhida da determinidade na eticidade absoluta somente se torna inteiramente visível pela negação simples da mesma no crime. A liberdade pura torna patente a 
idealidade da determinidade, isto é, a idealidade da posição das determinidades singulares enquanto estando em oposição à universalidade formal; mas, ao fazer do negativo sua essência, o ato criminoso revela que o que é posto na eticidade em relação é somente uma determinidade que não atinge a essência interior da existência social. Por isso mesmo, a negação criminosa é somente uma suspensão ideal da determinidade. Se esta negação fosse levada ao paroxismo, a objetividade seria completamente aniquilada, e também a subjetividade se aniquilaria como tal, o que significaria a dissolução da diferença em uma indiferença sem forma.

A tese de Hegel é, neste berço de sua concepção da negação autoreferencial ${ }^{32}$, que somente a negação da negação absoluta, isto é, a unificação de termos absolutamente contrapostos, é capaz de forjar a unidade absoluta que conecta eticamente os indivíduos. Seguindo suas reflexões em Frankfurt, segundo as quais a eticidade tem de ser compreendida como unidade substancial e não como conjunto de leis morais abstratamente universais, Hegel compreenderá a suspensão da eticidade através de atitudes excludentes como uma visão superficial e meramente aparente da relação entre universal e singular (KIMMERLE, 1970): a eticidade não pode ser compreendida como oposição "legalista" entre universalidade e singularidade, mas sim como o que somente emerge genuinamente enquanto uma superação da negação que fixa o negativo como determinidade, como ultrapassagem da negação que contrapõe ao "real" da eticidade natural o "ideal" da exclusão. Hegel compreende a "Aufhebung der Aufhebung" como uma suspensão da mera idealidade da suspensão apenas negativa da "exclusão criminosa”, perpetrada pela auto-contraposição da liberdade pura à unidade da vida ética. A suspensão da suspensão não desemboca, portanto, na aniquilação do real através de sua subsunção ao ideal, mas consiste antes em uma transformação da realidade em idealidade.

Eis porque, no processo de reconstrução parcial desta suspensão da suspensão no capítulo sobre o crime, tal como ocorrera em Frankfurt, não está em poder do criminoso se desvencilhar do "destino" em que se enreda, e seu ato se volta contra ele mesmo, de maneira que se conecta a ele

\footnotetext{
$32 \mathrm{Na}$ medida em que se constitui como negação e simultânea conservação da determinidade finita no absoluto, Schnädelbach compreende a Aufhebung der Aufhebung, da qual Hegel distingue, no System der Sittlichkeit, a suspensão meramente negativa, na qual a determinidade finita desaparece sem diferença na idealidade do absoluto, como a proto-forma da negação da negação e, portanto, como antecipação da negação determinada em relação à negação abstrata (SCHNÄDELBACH, 2000, 94)
} 
exteriormente uma justiça vingativa e, internamente, uma má consciência. Portanto, a gradual nulificação dos fenômenos do crime pela justiça vingativa desvela paulatinamente a estrutura do ético como tal: a negação do meramente subjetivo através de sua "posição como algo suspenso".

O alcance desta estrutura é comparado por Hegel com a negação da subjetividade de um indivíduo vivo no assassínio e seu retorno à indiferença da objetividade vital, onde a justiça punitiva acaba por se mostrar como a vida que se opõe à pretensão de auto-exclusão do assassino. "Um assassínio suspende o vivo enquanto singularidade, enquanto sujeito, mas a eticidade faz isto igualmente. Porém, a eticidade suspende a subjetividade, a determinidade ideal do mesmo, o assassínio, por sua vez, sua objetividade, põe-no como um negativo, particular, o qual retorna sob o poder do objetivo, do qual ele se destaca (dem es sich entriß) por meio disso: que ele mesmo era um objetivo.” (HEGEL, 1968, GW 5, 311) Tanto a eticidade quanto o assassínio visam à "suspensão" da subjetividade. Mas o assassínio é negação da singularidade que se realiza na morte do indivíduo vivo, o que demonstra, decerto, que o indivíduo em sua posição singular é uma determinidade ideal, mas também que se o "suspende" pela negação de sua realidade.

"A eticidade absoluta suspende imediatamente a subjetividade por meio disso: que ela a nadifica somente enquanto determinidade ideal, enquanto oposição, mas deixa subsistir a essência pura e simples dela ... A inteligência permanece na eticidade uma tal.” (HEGEL, 1968, GW 5, 309) Enquanto a suspensão ética da subjetividade implica em sua subsistência enquanto inteligência, o assassínio é negação da singularidade não somente como determinidade ideal, mas também e necessariamente como vitalidade real, pelo que a oposição é ratificada nos termos de uma auto-posição absoluta do assassino, o qual se mantém, assim, em relação com a vida de que se excluiu pela aniquilação. Entretanto, se, pelo seu ato, o assassino lesou a vida em uma determinidade singular, isto somente foi possível porque o indivíduo vivo é parte da vida. Eis porque o meio vital, que é condição da própria auto-exclusão do assassino, volta-se contra ele em nome de seu restabelecimento à condição original, mobiliza-se contra a pretensamente absoluta auto-exclusão do assassino: "tem-se de atuar contra esta negação. Já que a suspensão da determinidade é somente formal, então ela continua subsistindo, ela está posta idealmente, mas ela permanece em sua determinidade real. E a vida somente é lesada nela, não elevada; e por isso 
esta vida tem de ser restabelecida.” (HEGEL, 1968, GW 5, 312) A reação da vida desvela, na verdade, a precariedade da auto-exclusão do criminoso, isto é, a unilateralidade de sua pretensão de se pôr para fora do círculo vital. Esta reação se dirige, com efeito, à atestação da idealidade da auto-exclusão do criminoso, à suspensão de sua singularidade. "No que ele aparentemente lesou exteriormente e enquanto algo estranho a ele, o criminoso lesou, de maneira imediata, a si mesmo idealmente e se suspendeu. Nesta medida, o ato exterior é, ao mesmo tempo, um [ato] interior, o crime, cometido contra o estranho, [e], desta maneira, cometido contra ele mesmo.” (HEGEL, 1968, GW 5, 313)

Com efeito, a vida entra, enquanto universal lesado, em oposição e se torna assim também ideal: "a lesão da vida não pode, em sua efetividade, ser restabelecida ... esta se dirige à efetividade, e esta reconstrução somente pode ser uma [reconstrução] formal.” (HEGEL, 1968, GW 5, 312) Eis o que Hegel chama de justiça vingativa, oposição e conexão absoluta entre crime e universal lesado ${ }^{33}$. Desta maneira, estruturado como oposição entre crime e justiça punitiva, o capítulo discute, em geral, a aniquilação das formas societárias de relação intersubjetiva e, em vista de uma a este nível impossibilitada auto-intensificação dos laços comunitários, também a contraatuação, com vistas ao restabelecimento dos nichos sociais de indiferença, do universal lesado, enquanto justiça punitiva ${ }^{34}$.

33 "Com o crime está absolutamente em conexão a justiça vingativa ( $r$ äche nde Gerechtigkeit). É a absoluta necessidade que a liga, pois um é o contraposto do outro, um deles a subsunção contraposta do outro. $\mathrm{O}$ crime subsume, enquanto vivacidade negativa, enquanto o conceito que se constitui como intuição, o universal, objetivo, ideal. Inversamente, a justiça vingativa subsume, enquanto universal, objetivo, novamente aquela negação que se constitui como intuição." (HEGEL, 1968, GW 5, 312)

${ }^{34}$ Em Geist des Christentums, Hegel entende que a lesão do universal objetivo pelo singular, o crime, é remida pela culpa através de uma negação inversa e correspondente. Esta estrutura geral é também aquela da suspensão presente em System der Sittlichkeit. Entretanto, Hegel pretendia, em Geist des Christentums, atingir, com sua doutrina da pena como destino, a unidade ética genuína e originária através da reconciliação com a vida lesada. 0 destino, o qual se contrapõe, na pena, ao indivíduo como totalidade da vida lesada, somente pode ser reconciliado pelo amor, e não pela pena ela mesma. No paradigma da expiação penal, há, mesmo na circunstância de um restabelecimento do estado de universalidade pela pena, um recrudescimento e recuo do universal, na medida em que ele não pode ser reconciliado e em que ele permanece por isso sempre um poder exterior e ameaçador. Neste sentido, Hegel mantém, no System der Sittlichkeit, apenas a estrutura geral entre lei objetiva e pena, mas desvincula-se da temática da reconciliação e remissão pelo amor (GÖHLER, 1974, 393). A suspensão positiva, que tem seu eco na reconciliação pelo destino, não se efetiva no capítulo sobre o crime e, na terceira parte, não se dá do mesmo modo que em Frankfurt: a reconciliação ocorre não mais no plano da fraternidade e do perdão, mas antes, de maneira substancial, pela inserção da singularidade na unidade viva do povo e de sua organização estatal. Com efeito, a unidade efetivada da eticidade em System der 
O vínculo estabelecido no System der Sittlichkeit entre a concepção frankfurtiana da reconciliação e a adesão jenense à metafísica espinosana da substância (WILDT, 1983, 323) traz consigo, entretanto, uma diferenciação da concepção de suspensão do crime em Frankfurt e Jena ${ }^{35}$. Em Jena, Hegel sustenta que a inversão ideal do ato criminoso na má-consciência ${ }^{36}$ é algo ainda incompleto, uma vez que permanece algo meramente interior. "O tema aqui é a contra-atuação (Gegenwirkung) real ou inversão, e a [inversão] ideal, imediata, segundo a necessidade abstrata do conceito está em geral contida, mas, nesta forma da idealidade, é somente uma abstração e algo incompleto. Esta inversão real é a consciência moral (Gewissen), e [é] somente algo interior, não interior e exterior ao mesmo tempo, algo subjetivo, não ao mesmo tempo objetivo." (HEGEL, 1968, GW 5, 312) Por outro lado, esta incompletude é ela mesma um impulso à totalidade. "Porque ela é um interior, incompleto, então ela impele à sua totalidade. Ela denuncia, revela e trabalha por si mesma até que vê a contra-atuação ou inversão ameaçando exteriormente sua realidade e como seu inimigo defronte de si." (HEGEL, 1968, GW 5, 312) Como o desenvolvimento da má consciência se dirige até o ponto da contraposição a si da vida lesada, a reconciliação consiste na desistência do criminoso em afirmar sua determinidade excludente como criminoso e na sua conseqüente "tomada de consciência" e ratificação de sua natureza em geral enquanto vivo ${ }^{37}$. "Pela vitória nesta luta posta [entre a consciência moral e seu

Sittlichkeit constitui-se por uma "redução" da estrutura da reconciliação enunciada em Frankfurt à problemática da lesão e restabelecimento da lei enquanto universal fixo, voltada à absorção societária pré-estatal de todos os fenômenos negativos empiricamente relevantes de uma intensificação exacerbada da posição excludente da singularidade, que se posicionam por isso de maneira negativa e destrutiva em relação à universalidade comunitária e que, em nome de uma integração social estável e imanente à singularidade, têm de ser negados pelo universal.

${ }^{35}$ Emblematicamente, no System der Sittlichkeit, Hegel menciona que "o restabelecimento pela religião não se dirige à efetividade" (HEGEL, 1968, GW 5, 312) Para uma visão detalhada acerca desta diferença, (GÖHLER, 1974) e (SIEP, 1974)

36"A consciência desta sua própria aniquilação é um subjetivo, interior, ou seja, a má consciência (das böse Gewissen). Ela é, nesta medida, incompleta e tem de se apresentar exteriormente como justiça vingativa." (HEGEL, 1968, GW 5, 312) A consciência (Gewissen), enquanto aspecto ideal ou intra-subjetivo da relação entre crime e justiça vingativa, é compreendida por Schnädelbach como uma "instância psíquica passível de reconstrução a partir relações intersubjetivas da vida". (SCHNÄDELBACH, 2000, 94/95)

37 "Em seguida ela [a consciência moral, E.C.L] começa a se satisfazer, porque ela observa o começo de sua realidade nele. Ela produz um ataque a si, do que ela pudesse se defender, e através da defesa contra 0 ataque se tranqüiliza, pois que ela defende a exigência mais universal, a indiferença e totalidade - a saber: a vida, da qual mesmo a consciência moral é uma determinidade - contra a negação ameaçada." (HEGEL, 1968, GW 5, 312) 
inimigo E.C.L] se repete aquele impulso da consciência moral, e sua reconciliação está somente no risco de morte e cessa com este.” (HEGEL, 1968, GW 5, 312) Portanto, é pela exposição do singular ao risco de aniquilação que a vida o demove de sua exclusão e o demonstra como parte de si mesma ${ }^{38}$.

${ }^{38}$ Com isso, o risco de morte, o qual era, no Naturrechtsaufsatz, a suspensão do singular e o índice da unificação ética do mesmo com o povo, é compreendido aqui como "possibilidade da apresentação do singular ele mesmo enquanto totalidade", prenunciando os Jenaer Systementwürfe 1803/04 (SIEP, 1974, 163/168) 


\section{Referências bibliográficas}

ADORNO, T.W. e HORKHEIMER, M. 1985. Dialética do Esclarecimento: fragmentos filosóficos". Rio de Janeiro: Zahar.

BAUM, M. 1989. Die Entstehung der Hegelschen Dialektik. Bonn: Bouvier BONDELI, M. 1997. Der Kantianismus des jungen Hegel. Die Kant-Aneignung und Kant-Überwindung Hegels auf seinem Weg zum philosophischen System. Hamburg: Felix Meiner

1999. "Vom Kantianismus zur Kant-Kritik. Der junge Hegel in Bern und Frankfurt,“ in: BONDELI \& LINNENWEBER-LAMMERSKITTEN. Hegels Denkentwicklung in der Berner und Frankfurter Zeit. München: Fink Verlag.

BOURGEOIS, B. 1986. Le Droit Naturel de Hegel (1802-1803) Commentaire. Paris: Vrin

CRÉAU, A. 1991 Kommunikative Vernunft als "entmystifiziertes Schicksal". Denkmotive des frühen Hegel in der Theorie von J. Habermas. Berlin: Beltz Athenäum

CRUYSBERGS, P. 1986. Hegel's critique of modern natural law. In: WYLLEMAN, A. Hegel on the ethical life, religion and philosophy (1793 - 1807). Louvain: Louvain University Press

DÜSING, K. 1969. Spekulation und Reflexion. Zur Zusammenarbeit Schellings und Hegels in Jena.In: Hegel-Studien 5. Hamburg: Meiner . 1994. Die Entstehung des Spekulativen Idealismus. In: JAESCHKE, W. Transzendentalphilosophie und Spekulation. Hamburg: Meiner. 2004. Gesetz und Liebe. Untersuchungen zur Kantkritik und zum EthikEntwurf in Hegels Frankfurter Jugendscgriften.In MERKER, B. Subjektivität und Anerkennung. Frankfurt: Mentis

GILBERT, G. 1982. Critique et dialectique : l'itinéraire de Hegel à Iéna, (1801 - 1805). Bruxelles: Facultés Universitaires Saint-Louis HABERMAS, J. 1974. "Arbeit und Interaktion. Bemerkungen zu Hegels Jenenser 'Philosophie des Geites”. In: GÖHLER, G. Frühe politische Systeme. Frankfurt am Main: Ullstein.

. 1988. Der Philosophische Diskurs der Moderne. Frankfurt: Suhrkamp

HEGEL, G.W.F. 1995. Enciclopédia das Ciências Filosóficas. São Paulo: Loyola. . 1968. Gesammelte Werke. Hamburg: Felix Meiner 
. 2002. System der Sittlichkeit [Critik der Fichteschen Naturrechts], Hamburg:

Felix Meiner

. 1970. Werke in 20 Bände. Frankfurt am Main : Suhrkamp.

HONNETH, A. 1992. Kampf um Anerkennung. Zur moralischen Grammatik sozialer Konflikte. Frankfurt am Main: Suhrkamp.

HORSTMANN, R. 1973. Probleme der Wandlung in Hegels Jenaer Systemkonzeption. In: Philosophische Rundschau 19.

ILTING, K. 1974. Hegels Auseinandersetzung mit der aristotelischen Politik. In: GÖHLER, G. Frühe politische Systeme. Frankfurt am Main: Ullstein.

JAMME, C. 1988. Ein ungelehrtes Buch. Die philosophiesche Gemeinschaft zwischen Hölderlin und Hegel in Frankfurt 1797-1800, Bonn: Felix Meiner 1990 “'Jedes Lieblose ist Gewalt'. Der junge Hegel, Hölderlin und die Dialektik der Aufklärung”. In: JAMME, C. Der Weg zum System. Materialien zum jungen Hegel, Frankfurt am Main: Suhrkamp.

KANT, I. 1968. Kants Werke - Akademie Textausgabe. Berlin: Walter de Gruyter.

KIMMERLE, H. 1970. Das Problem der Abgeschlossenheit des Denkens. Hegels „System der Philosophie“ in den Jahren 1800-1804. Bonn: H. Bouvier

KOTKAVIRTA, J. 2004. "Liebe und Vereinigung”. In: MERKER, B. Subjektivität und Anerkennung. Frankfurt am Main: Mentis.

LEIJEN, A. 1986. "The intituition of the absolute concept in the absolute ethical life: Hegel's System of Ethical Life". In: WYLLEMAN, A. Hegel on the ethical life, religion and philosophy (1793 - 1807). Louvain: Louvain University Press.

LIMA, E. C. 2006. Direito e Intersubjetividade: eticidade moderna em Hegel e o conceito fichteano de reconhecimento. Campinas. 293 p. Tese de Doutorado em Filosofia, UNICAMP.

LUKÀCS, G. 1979. Die Verdinglichung und das Bewußtsein des Proletariats. In: Geschichte und klassenbewubtsein. Studien über marxistische Dialektik. Darmstadt: Luchterhand

.1986. Der junge Hegel und die Probleme der kapitalistischen Gesellschaft. Berlin/Weimar: Aufbau-Verlag.

MEIST, K. 1980 Hegels Systemkonzeption in der frühen Jenaerzeit, In: DÜSING, K. Hegel in Jena. Bonn: Bouvier.

.2002. Einleitung. In: G.W.F Hegel, System der Sittlichkeit [Critik des Fichteschen Naturrechts]. Hamburg: Felix Meiner.

Hegels Systemkonzeption in der frühen Jenaerzeit, In: DÜSING, K. Hegel in Jena. Bonn: Bouvier. 
MÜLLER, M. 2002. "O direito natural de Hegel: pressupostos especulativos da crítica ao contratualismo". In: Filosofia Política. Rio de Janeiro, 5, 41-66.

RIEDEL, M. 1969. "Hegels Kritik des Naturrechts". In: RIEDEL, M. Studien zu Hegels Rechtsphilosophie. Frankfurt am Main: Suhrkamp. . 1974. "Die Rezeption der Nationalökonomie". In: GÖHLER, G. Frühe politische Systeme. Frankfurt am Main: Ullstein.

SCHNÄDELBACH, H. 2000. Hegels praktische Philosophie: Ein Kommentar der Texte in der Reihenfolge ihrer Entstehung. Frankfurt am Main: Suhrkamp.

SIEP, L. Hegels Fichtekritik und die Wissenschaftslehre von 1804. München: Alber . 1974. Der Kampf um Anerkennung. Zu Hegels Auseinandersetzung mit

Hobbes in den Jenaer Schriften. In: Hegel-Studien 9. Bonn: Bouvier

1979. Anerkennung als Prinzip der praktischen Philosophie. Freiburg/München: Alber.

.2000. Der Weg der Phänomenologie des Geistes. Ein einführender Kommentar zu Hegels „Differenzschrift" und „Phänomenologie des Geistes“: Frankfurt: Suhrkamp

WILDT, A. 1983. Autonomie und Anerkennung. Hegels Moralitätskritik im Lichte seiner Fichte-Rezeption. Stuttgart: Klett-Cotta.

WYLLEMAN, A. 1989. Driven Forth to Science, in: WYLLEMAN, A. Hegel on the ethical life, religion and philosophy (1793 - 1807). Louvain: Louvain University Press.

ericklima74@hotmail.com

Recebido: agosto/2007 Aprovado: dezembro/2007 